LL는, BANCO CENTRAL DO BRASIL

Bailing in Banks: costs and benefits

Sergio Rubens Stancato de Souza, Thiago Christiano Silva e Carlos Eduardo de Almeida

September 2019

Working Papers
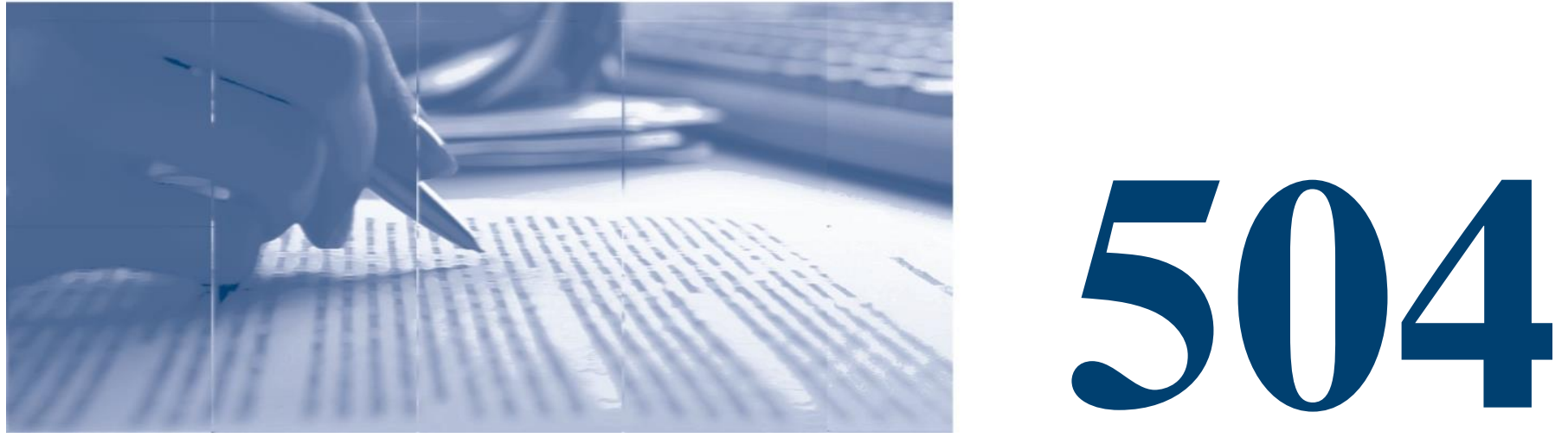
ISSN 1518-3548

CGC 00.038.166/0001-05 


\section{Working Paper Series}

Edited by the Research Department (Depep) - E-mail: workingpaper@bcb.gov.br

Editor: Francisco Marcos Rodrigues Figueiredo

Co-editor: José Valentim Machado Vicente

Head of the Research Department: André Minella

Deputy Governor for Economic Policy: Carlos Viana de Carvalho

The Banco Central do Brasil Working Papers are evaluated in double blind referee process.

Although the Working Papers often represent preliminary work, citation of source is required when used or reproduced.

The views expressed in this Working Paper are those of the authors and do not necessarily reflect those of the Banco Central do Brasil.

As opiniões expressas neste trabalho são exclusivamente do(s) autor(es) e não refletem, necessariamente, a visão do Banco Central do Brasil.

\section{Citizen Service Division}

Banco Central do Brasil

Deati/Diate

SBS - Quadra 3 - Bloco B - Edifício-Sede - $2^{\circ}$ subsolo

70074-900 Brasília - DF - Brazil

Toll Free: 08009792345

Fax: +55 (61) 3414-2553

Internet: http//www.bcb.gov.br/?CONTACTUS 


\section{Non-Technical Summary}

The global financial crisis in 2008 resulted in failures and recapitalizations of large banks in Europe and US that threatened public finances. Along this period, authorities frequently employed taxpayers' resources to bailout or nationalize banks. The crisis evidenced the need of improving tools to resolve failing or likely-to-fail systemic banks, leading the Financial Stability Board (FSB) to develop a new resolution framework to resolve distressed banks in an orderly manner, without resorting to taxpayer money. In this framework, known as bail-in, solvency support does not recur to public funds; instead, losses are absorbed with resources from shareholders and creditors.

We contribute to the banking literature by simulating bank bail-ins to study their effects on financial stability and on the funding of the real sector in Brazil. The Brazilian economy provides an ideal case study because firms must resort to bank credit to fund their activities. We measure the efficiency of bail-ins comparing the losses mitigated by a bail-in to losses that would occur if the banks under resolution were liquidated. Then, we evaluate credit crunches that would be potentially prevented by bailing-in banks instead of liquidating them in the upfront and analyze the effects that the liquidation of Domestic Systemically Important Banks (D-SIBs) would cause on bank lending to economic sectors. Finally, we build counterfactual scenarios of requirements for bail-inable instruments and study how they affect the likelihood of a successful bail-in. Our investigation intends to shed light on two important questions for Resolution Authorities. The first one refers to the extent of the contagion risks arising from write-downs and/or write-offs of creditors in a bail-in process, while the second refers to the adequacy of the current amount of bail-inable instruments to deal with distressed scenarios.

The simulations show bail-ins would be effective in mitigating credit crunch and contagion losses. In Brazil, 13 banks (all S1, two S2, four S3 and one S4) would benefit from a bail-in. Building counterfactual scenarios of requirements for bail-inable instruments, we find the number of small and medium banks that could benefit from a bail-in would grow substantially for small increases in requirements. We also find the trade sector would benefit the most in terms of credit crunch volume prevented by successful D-SIB bail-ins, while in percentage terms, human health and electricity \& gas would be the most benefited sectors. 


\section{Sumário Não Técnico}

A crise financeira global de 2008 ocasionou quebras e recapitalizações de grandes bancos na Europa e nos Estados Unidos, colocando as finanças públicas em risco. Para socorrer ou nacionalizar esses bancos, frequentemente foram empregados recursos dos contribuintes. Ficou clara a necessidade de aperfeiçoamento de ferramentas de resolução de bancos sistêmicos falidos ou com falência provável, levando o Financial Stability Board a desenvolver uma metodologia de resolução para atuar de maneira ordeira e sem uso do dinheiro do contribuinte. Nessa metodologia, conhecida por recapitalização interna, ou bail-in, as perdas são absorvidas com recursos dos acionistas e credores, sem uso do dinheiro dos contribuintes.

Contribuímos com a literatura utilizando simulações para estudar, sob diversas perspectivas, os impactos de bail-ins na estabilidade financeira e no financiamento ao setor real no Brasil. Estudar a economia brasileira é interessante porque o crédito bancário é uma importante fonte de financiamento para as firmas. Medimos a eficiência de um bail-in comparando a mitigação de perdas entre os casos de resolução com e sem bail-in. Em seguida, calculamos a restrição de crédito evitada pela adoção de bail-in em vez da liquidação de bancos e estimamos o impacto da liquidação de bancos sistemicamente importantes na concessão de crédito aos setores da economia. Por fim, construímos cenários contra factuais impondo requerimentos de instrumentos bail-ináveis para estudar seus efeitos na capacidade de absorção de perdas do sistema e a possibilidade de bail-ins serem bem-sucedidos no sistema. Essa investigação pode prover à Autoridade de Resolução uma ferramenta que lhe forneça duas informações importantes: a extensão dos riscos de contágio originários de extinções de dívidas durante um bail-in; e a adequação de um dado estoque de instrumentos bail-ináveis para fazer face a cenários de estresse.

As simulações mostram que bail-ins são eficazes na mitigação de restrições de crédito e na de perdas de contágio. No Brasil, 13 bancos (todos do S1, dois do S2, quatro do S3 e um do S4) se beneficiariam de um bail-in. Através de análises de cenários contra factuais, verificamos que o número de bancos pequenos e médios que se beneficiariam de um bail-in aumentaria substancialmente para um pequeno acréscimo nos requerimentos. Com relação ao volume da restrição de crédito evitada pelo bail-in de bancos sistêmicos no país, encontramos que o setor de Comércio seria o mais beneficiado, seguido pelo setor de Indústrias de Transformação. Em termos percentuais, os setores mais beneficiados seriam os de Saúde e Eletricidade e Gás. 


\title{
Bailing in Banks: costs and benefits
}

\author{
Sergio Rubens Stancato de Souza* \\ Thiago Christiano Silva** \\ Carlos Eduardo de Almeida ${ }^{* * *}$
}

\begin{abstract}
We investigate the effectiveness of bail-in mechanisms in mitigating systemic risk and welfare costs to society during resolution processes. To perform this study, we define a network model of mutually exposed banks and use it to simulate the effects of shocks to these banks using granular data of the Brazilian banking system, its interbank exposures and credit register operations. In the simulations, we compare the outcomes of these initial shocks after resolution processes with and without bail-ins. The simulations show that by avoiding the liquidation of banks and the resulting interruption in their credit provision, bail-ins would be effective in preventing the amplification of losses imposed on the real sector. Analyzing the effects that the liquidation of Brazilian Domestic Systemically Important Banks (D-SIBs) would cause to credit provision to economic sectors, we find bailing in these banks would produce a relevant decrease in credit crunches. However, in our sample, only a few banks could benefit from bail-ins due to insufficiency of bail-inable instruments. To tackle this issue, we carry out a study based on counterfactual simulations to assess if and how setting requirements for bail-inable instruments would affect the likelihood of a successful bailin. We find the number of small and medium banks that could benefit from a bail-in would grow substantially for small increases in these requirements.
\end{abstract}

Keywords: banking system, resolution, bail-in, contagion, networks.

JEL Classification: G21, E58, G28, C63.

The Working Papers should not be reported as representing the views of the Banco Central do Brasil. The views expressed in the papers are those of the authors and do not necessarily reflect those of the Banco Central do Brasil.

\footnotetext{
*Research Department, Central Bank of Brazil. E-mail: sergio.souza@bcb.gov.br

** Research Department, Central Bank of Brazil. E-mail: thiago.silva@bcb.gov.br

*** Resolution Regimes Department, Central Bank of Brazil. E-mail: carlos.e.almeida@bcb.gov.br
} 


\section{Introduction}

The financial crisis in 2008 strongly hit 22 countries in Europe and North America, resulting in failures of large banks ${ }^{1}$ and many other banking recapitalizations that threatened public finances. During this period, authorities applied a recurrent strategy of granting guarantees over deposits and/or of using public resources to bailout (or nationalize) banks. Therefore, taxpayers essentially bore the cost of resolving the financial crisis. ${ }^{2}$

Philippon and Salord (2017) estimate American authorities injected almost 6\% of 2008 GDP to restore the normal functioning of American too-big-to-fail banks ${ }^{3}$ In Europe, the amount injected was about $4.6 \%$ of their aggregate annual GDP up to 2012. European taxpayers covered more than two thirds of resolution costs. The authors argue taxpayers' costs would have been halved if $8 \%$ of the assets of the private sector in Europe had been used to absorb these losses upfront. These episodes highlight the high degree of financial interconnectedness in society and financial systems worldwide, feature that enabled regional or localized shocks—-such as bank-specific negative events-to turn into widespread systemic risk events due to network spillovers.

The global financial crisis also evidenced the lack of tools to resolve failing or likely-to-fail systemic banks and impaired authorities' credibility. The Financial Stability Board (FSB) responded by developing the bail-in, a new resolution framework to resolve distressed banks in an orderly manner without resorting to taxpayer money. The bail-in prescribes ex-ante resolution planning without the use of public funds for solvency support. Under this process, shareholders and creditors are forced to share the burden of losses.

During a bail-in, losses are first absorbed by equities, followed by hybrid and subordinated debts, which are converted to capital and then employed to absorb remaining losses. After losses are absorbed, the bank is recapitalized to a target recapitalization level, which should be high enough to withstand additional losses that could result from further instabilities. The bail-in does not create expectation that the Government will rescue systemic banks, thereby improving market discipline and reducing moral hazard and excessive risk-taking.

This paper contributes to the banking literature in several aspects by assessing the effectiveness of bail-ins in mitigating systemic risk in the economy using a network model. First, to compute the bail-in effectiveness, we take as baseline the resolution process in which a bank is simply liquidated. Then, we denominate the bail-in effectiveness the amount of losses that would be mitigated were that bank bailed in instead. Second, our work departs from the existing literature by explicitly considering the bail-in effects on the real sector, besides the existing analyses limited to the financial sector. To do so, we evaluate credit crunches that would be potentially prevented by bailing in banks instead of

\footnotetext{
${ }^{1}$ For instance, Fortis - Belgium, Lehman Brothers - USA, three major Icelandic banks, Anglo Irish Bank - Ireland and Dexia - France and Belgium.

2 Laeven and Valencia (2012) provide a comprehensive report and detailed numbers about the interventions that occurred during the global financial crisis.

${ }^{3}$ In the fourth quarter of 2008, the American authorities took measures to minimize potential losses from the ongoing financial crisis, which included the Troubled Asset Relief Program (TARP). This program intended to rescue US financial institutions by employing public funds to purchase their low quality equities.
} 
liquidating them upfront. Third, we construct counterfactual scenarios of requirements for bail-inable instruments and study how they would affect the likelihood of a successful bail-in. The objective of this analysis is to propose a framework for supporting policymakers in their task of defining parameters of the bail-in process such as to increase the number of banks that would be successfully bailed in.

We do not compare bail-outs with bail-ins in our analysis of the bail-in effectiveness due to several reasons. Even though bail-outs-just like bail-ins-reduce liquidation costs, interbank market contagion and a potential credit crunch. 4 they promote market indiscipline and foster moral hazard by disordering incentives of who takes the risk and who pays for the losses. Bail-ins, in contrast, intend to promote market discipline and align incentives: investors must adjust their risk appetite considering that they will bear losses if the bank receiving investment fails, regardless of its systemic importance. Such mechanism discards the possibility of losses being borne by taxpayers.

In fact, a complete assessment of the benefits of bailing in a bank in comparison with liquidating it would comprise the outcome evaluation of adopting these alternatives on the whole economy, including not only the credit crunch from the banking sector but also the corresponding reaction of the real sector to the banking system. We do not model this reaction, that is, we just compute the credit shocks arising from these resolution schemes that the real sector would potentially experience. This limitation makes our model particularly useful for understanding the short-term consequences associated with the bail-in for the economy.

We not only compute the losses that a potential bail-in would prevent on the resolved bank's counterparts, but also evaluate the potential quarterly decrease on bank credit supply prevented by bailing in the bank instead of liquidating it. To compare the amount of bank credit crunch arising from bailing in the bank to that from liquidating it, we consider as baseline the bank to be intervened is already under financial distress, i.e., its credit supply is constrained before the intervention begins. We assume a bail-in does not worsen the credit supply as it improves the bank's capitalization. 5 In comparison, in case of liquidation, the bank stops operating, and its borrowers are forced to seek other credit relationships. We assume in the short term, firms do not find satisfactory borrowing conditions to substitute those they had from the liquidated bank.

Computing this credit restraint is important for resolution authorities, because it is a crucial factor to consider when deciding to liquidate or bail-in a bank. In times in which the banking system is less capitalized, regulatory constraints faced by banks may limit lending to the real sector due to capital requirements. In this case, the additional demand for bank credit arising from the real sector due to the liquidation of the bank might not be satisfactorily absorbed by remainder banks, affecting firm output and activities 6 Contractual credit terms could worsen as well in view of the sudden increase in credit

\footnotetext{
${ }^{4}$ We thank an anonymous referee for this comment.

${ }^{5}$ The approach adopted here is complementary to that in Beck et al. (2017). In this paper, we consider as baseline the situation in which the lending bank is in stress and possibly has already reduced its credit supply. Then, we compare this situation with another in which that bank is liquidated and cannot operate. In turn, Beck et al. (2017) consider as baseline firms not exposed to banks under distress and compare them with firms exposed to banks that have been bailed in. Using a panel model, they find firms exposed to banks that were bailed in experience negative effects when they are not able to replace bank-firm relationships with others in equal terms.

${ }^{6}$ In addition, the reduction of firm activity levels may reduce its demand for goods and services from suppliers. Thus credit demand from the real sector could decrease as well. However, we do not take this effect into account in our model.
} 
demand, thus increasing external financing costs.7 Our work sheds light to resolution authorities in the sense that the decision for bailing in a bank not only has to encompass consequences for the financial sector-such as potential contagion-but also spillovers to the real sector.

To compute the short-term credit crunch, we consider the average flow of new loans in a given unit of time instead of computing it over a fixed period whose length would have to be assumed or measured. Thus, we evaluate the average credit crunch as the sum of new loans granted by the bank that would be intervened during the quarter just before liquidation. We suppose in this period the bank will be already under stress and that, if it is bailed in, the credit it is able to grant will remain roughly the same. However, if it is liquidated, it will not continue to operate and, just after liquidation, this average flow of new loans per quarter will be the additional credit demand per quarter faced by other lenders. Besides computing this instantaneous credit crunch, we compute its ratio to the outstanding credit and to the banking system's new credit granted in that quarter to provide the average impact on credit caused by the liquidation under study.

Our methodology is based on a representation of the banking system as a network of interbank bilateral exposures and evaluates the loss amplification that arises from network relationships. Basically, the model takes as input an external shock to one or more banks and repeats, until equilibrium, two steps: the resolution process, for non-compliant banks, and the resulting loss propagation within the network. 8 In our framework, banks are imposed to respect Basel III capital requirements. We compare the results from simulations of two types: one featuring a resolution process that liquidates non-compliant banks, and another in which the Resolution Authority attempts to bail-in non-compliant banks. If that attempt does not succeed, that is, if the amount of the bank's bail-inable instruments is insufficient for the bail-in, the bank is liquidated. We evaluate the bail-in efficiency as the difference between the losses computed using the bank resolution procedure that allows only bank liquidations (baseline model) and those computed according to the resolution procedure that attempts bailing in banks (target model) for the same shock scenario.

Using our methodology, we simulate different stress scenarios to uncover the consequences, for the interbank market, of loss allocations performed by the resolution processes studied in this paper. We find that 13 out of 131 banks in Brazil would benefit from a bail-in scheme in December 2016. The majority of these banks would not benefit from successful bail-ins because they have, on average, insufficient levels of bail-inable resources. In this scenario, the introduction of bail-ins would not, in general, prevent many potential bank liquidations. In a different simulation, we study the efficiency of successfully bailing-in each of the Brazilian domestic systemically important banks (D-SIBs). We find the efficiency of successful bail-ins in preventing credit crunches varies largely across economic sectors. We also find successful bail-ins usually reduce systemic risk. Considering lending volumes, the trade sector would benefit the most from the introduction of bail-ins, followed by the manufacturing

\footnotetext{
${ }^{7}$ This effect is even more pronounced in bank-oriented economies, such as Brazil. An average firm in Brazil only has external funding access in the form of bank credit, since capital markets are restricted to large firms. Therefore, the credit crunch is an important factor to be accounted for when deciding the proper resolution strategy for a failing bank.

${ }^{8} \mathrm{We}$ do not address in this paper the discussion regarding the importance of emergency liquidity assistance or asset valuation during a resolution process. We also do not model the consequences neither of liquidity hoarding nor of reputation contagion, therefore, our results on benefits to society are conservative.
} 
sector. In percentage terms, the human health and electricity \& gas would be the most benefited sectors.

Our methodology allows us to set levels of requirements of bail-inable instruments to be held by banks. We use this flexibility to perform a sensitivity analysis by gradually increasing the bailinable instruments' requirement ratios and checking the corresponding number of banks that would be successfully bailed in (bail-inable banks). In our Brazilian case study, we find that all large banks have enough resources for a minimum recapitalization bail-in $\sqrt[9]{9}$ but, for a full recapitalization $\sqrt[10]{ }$ more than half of them would need a bail-inable instruments requirement ratio of 0.15 or more. The number of bail-inable banks would grow substantially for small increases in the requirements for small and medium banks. These findings are related to the comparison of the target recapitalization required by the bail-in to the amount of potentially bail-inable instruments of the bank. ${ }^{11}$ Regarding the amounts of bail-inable and non-bail-inable instruments, the balance sheet composition of single smaller banks varies more than that of single large banks, which explains the greater sensitivity of the number of bail-inable banks from those categories to requirements of bail-inable instruments.

Despite the positive externalities of bail-ins ${ }^{12}$ Schoenmaker (2017) argues that if bail-inable debt is held mostly by the banking sector, a significant write-down would impose losses to other banks, weakening the banking system, especially in times of crises, when it would be necessary to bail-in more than a single bank. Systemic risk mitigation could then be minimal. In our case study, we find more than $73 \%$ of bail-inable resources are held by agents other than banks. The small amount held by banks (27\%) is largely issued by large banks, which often are highly capitalized. In this way, the introduction of the bail-in as a bank resolution mechanism-while inefficient for most banks due to their insufficient levels of bail-inable instruments-would not produce significant negative effects to the financial stability in Brazil.

The remainder of the paper is structured as follows. Section 2 connects our work with the related literature. Section 3 describes the institutional context related to bail-ins. Section 4 defines our methodology. Section 5 explores the confidential Brazilian data we use to perform our case study. Section 6 discusses our empirical findings using Brazilian data. Finally, Section 7 concludes.

\section{Related literature}

The results in this paper touch on several strands of the literature. The paper closely relates to the banking literature segment that focuses on bank resolution mechanisms. Conlon and Cotter (2014) examine the use of bail-in tools for European banks that went bankrupt during global financial crises. They find that equity and subordinated bond holders would have been the main losers in that scenario. 13

\footnotetext{
${ }^{9} \mathrm{~A}$ minimum recapitalization bail-in is a bail-in in which the bank has just breached capital requirements. In this case, the bail-inable resources are employed only to increase the capitalization to the target level defined for the bail-in.

${ }^{10}$ Recapitalization from a zero capital buffer level to the target capital level.

${ }^{11}$ All subordinated debt instruments and all senior uninsured unsecured debt instruments are potentially bail-inable. The list of bail-inable instruments is specified by the Resolution Authority.

${ }^{12}$ Among the externalities, we highlight: reduction of the need of taxpayer money, promotion of market discipline and creation of incentives to reduce the risk appetite of banks

13 Martynova and Perotti (2018) show how contingent capital affects banks' risk choices. They find contingent capital is less risky than bail-inable debt as its lower priority is compensated by a lower induced risk-taking behavior of banks.
} 
Klimek et al. (2015) look at different bank resolution mechanisms-purchase and assumption, bailout and bail-in - as tools for crisis resolution management and find the best bank resolution choice for given conditions. Such work differs from ours in the sense they propose a stylized model that enables theoretical comparisons among different bank resolution mechanisms. In contrast, our work is an applied study, which uses real data and can be readily employed by the Resolution Authority to identify and understand the consequences of bail-ins for financial stability.

The paper also shares some insights with the bank regulation literature. Lehmann (2017) investigates the structural weaknesses of bail-ins from a legal perspective in a cross-country study. $\mathrm{He}$ illustrates the conflict between bail-in resolution and private international law: while a bail-in can be legally enforced by states with territorially limited powers, affected entities or groups may take part in global activities and have assets in many countries. Under traditional rules of private international law, these activities and assets would then be governed by the law of other states. ${ }^{14}$ In our work, we show concerns with global assets and activities are somewhat minimized, because Brazilian banks have comparatively low international exposures.

Our paper also relates to the literature assessing the propagation of shocks in the interbank market due to direct contagion. Systemic risk estimation using network models broadly falls into two categories: loss- (Eisenberg and Noe, 2001) and stress-based (Battiston et al. 2012) methods. ${ }^{15}$ While lossbased models are useful to identify the real consequences of large shocks or bank defaults in a financial system, stress-based models are important quantitative tools to understand systemic risk buildup. The second methodology is more sensitive to small shocks that do not lead banks to bankruptcy. Most of these methods consider bank liquidations as the only resolution mechanism. One exception is Hüser et al. (2018), to which our work is closely related, that takes into account bail-ins in a network model. Our paper differs from that work in several dimensions. We attempt to quantify losses that would be prevented by successful bail-ins and constraints in the credit supply to the real sector (credit crunches). We also take a granular look at which economic sectors and types of credit would benefit the most from the adoption of bail-ins. Finally, we study a hypothetical adoption of requirements for bail-inable instruments in Brazil to draw some important insights for bank regulation and financial stability. Rather than saying whether the current level of Bail-inable instruments is adequate or not, this methodology provides inputs for the policy-makers' debate about loss absorbency capacity.

\section{Institutional background: the bail-in}

The global financial crisis made clear the inability of authorities to deal with the fast propagation of losses across the globe. The highly integrated markets required a macroprudential approach to complement the prevailing microprudential approach in surveillance. Additionally, authorities could not

\footnotetext{
${ }^{14}$ In the same vein, Tröger $(2018)$ highlights the high complexity involved in the bail-in process in the context of the European Union. He concludes that the European resolution framework is likely ineffective in establishing adequate market discipline through risk-reflecting prices for bank capital.

${ }^{15}$ Several extensions have been proposed in the network modeling for systemic risk after these seminal papers. We highlight the models in Bardoscia et al. (2015); Martinez-Jaramillo et al. (2014); Silva et al. (2017a, 2016, 2017b); Souza (2016); Souza et al. (2016) and Poledna et al. (2015).
} 
minimize losses due to the lack of tools to resolve failing or likely-to-fail systemic banks. To deal with the latter issue, the G-20 countries called the Financial Stability Board (FSB) to tackle the challenge of developing a new resolution framework that allows resolving distressed banks in an orderly manner, without recurring to taxpayer money.

In reply, the FSB developed the framework described in the Key Attributes of Effective Resolution Regimes for Financial Institutions 16 (FSB, 2014). The Key Attributes delineate the directives, tools and powers needed to resolve a failing bank while mitigating adverse externalities. The framework assumes that resolution regimes must provide financial stability by ensuring the continuity of systemically critical functions (e.g. financial services, payments, clearing and settlement functions) without the support of public money. In addition, they should be transparent and as predictable as possible through legal and procedural clarity.

The Key Attributes advocate a resolution framework should be supported by an ex-ante resolution planning to allow prompt intervention of resolution authorities to safeguard the public interest. To reduce moral hazard and mitigate the implicit guarantee of the so called "too-big-to-fail banks," the core resolution strategy is to allocate losses to firm owners (shareholders) and creditors of unsecured and/or uninsured debt, respecting the hierarchy of their claims, while avoiding unnecessary destruction of value. Using internal resources for loss absorption is the key principle of a bail-in. The rationale behind bail-ins is quite simple: investors must believe they will bear losses during the resolution of the failing bank, despite of its systemic importance, instead of relying on a rescue with public funds. This message, conveyed by the new resolution framework, is beneficial as it enhances market discipline and provides incentives for market-based solutions. Financial stability is improved as market agents receive incentive to avoid excessive risk-taking.

The adoption of bail-ins as part of the resolution toolkit has no evidence of shading the role of the resolution authority in maintaining financial stability. In a survey conducted by Jansen et al. (2013) in the Netherlands after the failures of two banks in 2008 and the public bailout of other two banks, ${ }^{17}$ the authors show that governmental interventions in banks do not lead the public to perceive the financial system as becoming less safe. The most iconic adoption of the bail-in as a resolution tool was in Cyprus where, notwithstanding a doubtful implementation, the results were positive, with its benefits surpassing its costs (Philippon and Salord (2017) 18 .

\footnotetext{
${ }^{16}$ According to FSB (2014), the aim of the Key Attributes is to propose a resolution framework that makes it possible to resolve any financial institution in an orderly manner without severe systemic disruption or exposing taxpayers to the risk of loss, by protecting the firm's functions that are critical to the financial market or to the real economy and ensuring that losses are borne by shareholders and creditors of the failing firm, as they would be insolvent. More information: http://www.fsb.org/what-we-do/policy-development/effective-resolution-regimes-and-policies/.

${ }^{1 /}$ Bankruptcy: Landsbanksi/Icesave (2008); DSB Bank (2009). Government's support: ING and SNS REAAL (2008). The Dutch government also nationalized parts of Fortis Bank and ABN Amro.

${ }^{18}$ Philippon and Salord (2017): "Most of the Cypriot programme's $€ 10$ billion was used to roll over public debt and cover deficits, and relatively little was lost on bailing out the banks (€1 billion to recapitalised cooperative banks). As the macroeconomic performance of Cyprus is decent, especially compared to other Eurozone countries in trouble, the logical conclusion is that the benefits of bail-in must be large, since they more than make up for all the costs."
} 


\section{Methodology}

In this section, we present the underpinnings of our methodology. We begin with a discussion of bank resolution regimes, especially the bail-in and its associated rules. Then, we describe the quantitative framework that we use to test the resilience of the banking system in view of external shocks. To assess the effectiveness of the model, we compare our financial stability framework with and without the adoption of the bail-in scheme using a common systemic risk measure: the differential DebtRank.

\subsection{The bail-in process}

FSB (2014) states features that permeate a sound resolution process. Among them, we highlight ${ }^{19}$ (1) losses must be initially allocated to shareholders and to holders of subordinated debts; (2) there is the possibility that losses are imposed to holders of senior uninsured and unsecured debts; (3) a Resolution Fund must be set up, which will provide financial assistance to banks facing resolution before the recourse to public funds: ${ }^{20}$ and (4) the resolution regime should consider the recourse to a public backstop funding. In the case of use of public resources, these should be repaid to the Treasury by the Resolution Fund participants through "ex-post contributions." In this scheme, taxpayers would be the first creditors to receive repayment upon the solution of the crisis. According to Schoenmaker (2017), making public funding available leads to a loss of market discipline. On the other hand, Cechetti and Schoenholtz (2017) state a resolution regime without the possibility of government funding in extreme circumstances is not credible. This lack of credibility would create an expectation that the government would enact a bail-out during a crisis, which also weakens market discipline.

The bail-in process studied in this paper covers the first two points above. Generally speaking, we trigger the bail-in when banks hit a predefined capitalization condition and then we proceed to their recapitalization using resources from bank owners and associated debt holders. We define this bail-in process as follows:

a) The banking system surveillance checks the capitalization level of the bank. If it is not compliant with Basel III requirements, it will decide on the start of a bail-in process. Normally, this decision is based on the lack of prospects that the bank will recover by its own means or by its systemic importance.

b) The bail-in consists of building up a class hierarchy of instruments (bank owners and debt holders) that is used to orderly absorb losses. Instruments in lower hierarchical classes must be completely depleted during the bail-in before higher classes contribute. In this paper, these hierarchical classes are denominated as seniority classes. They are, from the lowest to the highest: (i) shareholders' equities, (ii) subordinated/convertible debt instruments and (iii) senior uninsured unsecured debt. For non-D-SIBs, senior debt instruments are not bail-inable. D-SIBs, in turn, can use these instruments if they are held by banks, avoiding bank runs that would occur if they were held by depositors.

\footnotetext{
${ }^{19}$ Brazilian regulators are developing a new resolution framework that dictates bail-in resolution mechanisms and that follow FSB (2014)'s principles in Brazil.

${ }^{20}$ To reduce moral hazard, banks should finance the Resolution Fund with monthly contributions.
} 
c) If a bank does not have enough bail-inable debt to withstand the losses, all seniority classes are consumed and the bank is liquidated afterwards.

d) In the liquidation process modeled here, there are two possible approaches: in a short-term approach, the bank continues to receive repayments from debtors but repayments to creditors remain frozen. Assets posted as collateral in secured operations are not frozen. In the long-term approach, there is no freezing, and the bank repays their creditors with the residual assets. In the short-term approach, these assets are denoted as "assets for recovery" as they are frozen for a time lapse. In this case, we consider that the liquidation cost is the amount of frozen assets.

e) The bail-in process has two phases. The first is the allocation of losses following the seniority classes. The purpose of this phase is to adjust the liability side of the bank's balance sheet so that it is worth the same as its assets after incurred losses. This adjustment follows the creditor hierarchy of bail-inable instruments as discussed in item (b). The adjustments consist in writingdown bail-inable resources until total liabilities match total assets after the shock. Within the same seniority class, we consider a pro rata scheme, such that holders of bail-inable resources are affected proportionally. When holders are banks, this writing down can give rise to contagion. To model the hierarchical nature of seniority classes, we consider the interbank exposures network as a multilayered network, in which each layer corresponds to a seniority class.

f) The second phase comprises recapitalizing banks until they reach a target capitalization level. A sound recapitalization level would be the median level attained by other similar bank peers. While this phase theoretically does not impose losses to bail-inable instrument holders, it affects the risk related to these holdings. This phase only starts after all losses are properly absorbed by the seniority classes and consists in converting the remainder bail-inable instruments into capital. This conversion also follows the seniority order. If the remainder bail-inable debt is insufficient, the bank is liquidated.

In Appendix A, we provide an example of application of the bail-in process described above under different loss scenarios.

\subsection{Resolution process with a bail-in}

This section discusses the set of rules we use to model bank bail-ins. We assume banks hold assets and liabilities inside and outside the interbank market. Denote $\mathscr{B}=\{1, \ldots, N\}$ as the set of $N$ banks in the economy. The mutual exposures of banks inside the interbank market give rise to a directed graph in which contagion and loss amplification through contagion can potentially take place. The balance sheet of bank $i \in \mathscr{B}$ is given by: 


$$
\begin{aligned}
A_{i} & =D_{i}+e_{i}, \\
A_{i} & =A_{i}^{C}+A_{i}^{F}, \\
D_{i} & =\sum_{c} D_{i}^{c}, \\
D_{i}^{c} & =d_{i}^{c}+d_{i}^{e, c}, \\
d_{i}^{c} & =\sum_{j} L_{i j}^{c}, \\
e_{i} & =s_{i}^{e}+\sum_{j} s_{i j} .
\end{aligned}
$$

Equation (1) is the fundamental accounting identity, in which $A_{i}, D_{i}$ and $e_{i}$ are the total assets, liabilities and equity of bank $i$. Equation (2) divides the asset composition into $A_{i}^{F}$, which represents fixed assets, excluding long term loans and securities, and $A_{i}^{C}$, which indicates the current assets plus long-term loans and securities. This division will later be used to evaluate the risk-weighted assets of banks. Equation (3) shows total liabilities as a sum of liabilities divided into their seniority classes $c \in\{1, \ldots, C\}, D_{i}^{c}$, from the lowest $(c=1)$ to the highest $(c=C)$. Equation (4) further segregates liabilities of the same seniority $c$ in terms of debts held inside the banking system, $d_{i}^{c}$, and outside the banking system, $d_{i}^{e, c}$.

Equation (5) indicates that bank $i$ 's total debt of seniority $c$ is the sum of its individual liabilities to every creditor bank $j$ in the interbank market, $L_{i j}^{c}$. For each debt seniority class $c$, there is a network of bank exposures. In this way, we have a multilayer network, in which each layer represents a debt seniority class. In a similar vein, Equation (6) treats the composition of bank equity in terms of the sum of shares held by agents outside the banking system, $s_{i}^{e}$, and held by other bank counterparty $j$ inside the banking system, $s_{i j}$. The set of all bank cross-holdings gives rise to a unilayer network.

Our framework assesses the need of triggering bail-in or liquidation mechanisms when the banking system experiences negative events. These bank resolution actions can impose losses to creditors of banks undergoing resolution. In this way, we need to recursively apply our procedure to these affected banks until no new bank enters resolution. The model considers how these aspects of spillovers arise and how interconnectedness can accentuate these effects in nontrivial ways. We use Eisenberg and Noe (2001)'s clearing algorithm to account for this iterative loss propagation process.

The loss propagation takes place at a given date. Spillovers to creditor banks do not represent the evolution of the banking system over time and are assumed to occur immediately after the external event takes place. Time indexes in our model represent iterations of a nonlinear dynamic system. Therefore, our model is not multiperiod and is particularly useful to understanding the short-term consequences of negative shocks on the banking system.

At iteration $t=0$, all variables start with values representing the actual state of the banking system (exogenous variables). Then, we impose a shock that impacts a specific or a set of banks. With no loss of generality, we assume that the shock solely influences bank $i$, leading to losses of $\Delta \varepsilon_{i}(0)$. In 
the first iteration, we have $\varepsilon_{i}(1)=\Delta \varepsilon_{i}(0)$. In what follows, every variable refers to iteration $t$, if not explicitly specified.

Banks must maintain a minimum regulatory capital corresponding to the requirement ratio $F^{T}=$ $100 \frac{K R_{i}^{T}}{R W A_{i}}$, in which $K R_{i}^{T}$ is the total regulatory capital requirement 21 and $R W A_{i}$ is the risk-weighted assets. In turn, $R W A_{i}=w_{i}\left(A_{i}^{C}-R B_{i}\right)$, in which $\left(A_{i}^{C}-R B_{i}\right)$ are the risky assets after deducting bank reserves $R B_{i}$, and $w_{i}$ is the risk weight ${ }^{22}$ In this way, the risk weight of bank $i$ is given by:

$$
w_{i}=100 \frac{K R_{i}^{T}}{F^{T}\left(A_{i}^{C}-R B_{i}\right)} .
$$

\subsubsection{Allocation of losses to the bank's capital}

We take bank $i$ as the reference in this section. With no loss of generality, we assume that such bank experiences an external shock ${ }^{23}$ In the first part, we delineate how losses are registered and recognized by bank $i$ (local effect). Losses do not settle down in the bank that the shock directly hits. Counterparts that hold shares of bank $i$ will have their capital reduced as well (network effect). The last part of the section deals with this spillover.

Local effect. Initially, we update bank $i$ 's assets to incorporate the losses to the balance sheet from the previous iteration:

$$
\begin{aligned}
& A_{i}(t)=A_{i}(0)-\varepsilon_{i}(t), \\
& A_{i}^{C}(t)=\max \left[A_{i}^{C}(0)-\varepsilon_{i}(t), 0\right] .
\end{aligned}
$$

These changes affect the bank's risk-weighted assets:

$$
R W A_{i}(t)=w_{i}\left[A_{i}^{C}(t)-R B_{i}\right]
$$

Losses are first absorbed by the bank capital. If it is not enough, the non-absorbed losses reach liabilities that are subject to the bail-in, which are consumed in increasing order of seniority.

We start by showing how bank capital is employed to absorb shocks. We define the bank $i$ 's capital buffer at iteration $t, K_{i}^{B}(t)$, as the sum of its shares, capital reserves and retained earnings. The dynamic of the loss absorption using bank capital is governed by the following expression:

\footnotetext{
${ }^{21}$ We evaluate the total regulatory capital requirements as the sum of Tier 1 and Tier 2 capital requirements.

${ }^{22}$ We assume a single representative class of risky assets. In this way, we only need to keep track of a risk weight $w$.

${ }^{23}$ The same reasoning applies in an additive manner if more than a single bank receives the shock.
} 


$$
W D_{i}^{S}(t)=\min \left[K_{i}^{B}(t-1), \Delta \varepsilon_{i}(t-1)\right],
$$

in which $W D_{i}^{s}(t)$ is the written-down amount of bank $i$ 's capital due to the external shock.

We recognize bank $i$ 's capital loss by subtracting the written-down losses from bank $i$ 's capitalization variables:

$$
\begin{aligned}
& e_{i}(t)=e_{i}(t-1)-W D_{i}^{S}(t), \\
& K_{i}^{B}(t)=K_{i}^{B}(t-1)-W D_{i}^{s}(t), \\
& K_{i}^{C}(t)=K_{i}^{C}(t-1)-W D_{i}^{S}(t), \\
& K_{i}^{T 1}(t)=K_{i}^{T 1}(t-1)-W D_{i}^{S}(t), \\
& K_{i}^{T}(t)=K_{i}^{T}(t-1)-W D_{i}^{S}(t),
\end{aligned}
$$

in which $K_{i}^{C}(t)$ refers to the bank $i$ 's Core Capital, $K_{i}^{T 1}(t)$, to its Tier 1 Capital, and $K_{i}^{T}(t)$ to its Total Capital. These variables are part of the baseline macroprudential restrictions imposed by Basel III to ensure the financial soundness of banks.

Network effect. The capital reduction of bank $i$ affects other banks that hold shares of such bank. We allocate losses proportionally to the shareholder's exposure share in the cross-holding network exposure. If $s_{i j}(t-1)$ represents the shares of bank $i$ held by bank $j$ at iteration $t-1$, then the reduction of bank $i$ 's capital by $W D_{i}^{s}(t)$ at iteration $t$ causes the shareholder bank $j$ to adjust $s_{i j}(t)$ as follows:

$$
s_{i j}(t)= \begin{cases}0, & \text { if } K_{i}^{B}(t-1)=0 \\ {\left[1-\frac{W D_{i}^{s}(t)}{K_{i}^{B}(t-1)}\right] s_{i j}(t-1),} & \text { otherwise }\end{cases}
$$

i.e., if the entire capital of bank $i$ is depleted $\left(K_{i}^{B}(t-1)=0\right)$, then the shares value vanishes. Otherwise, it proportionally reduces in accordance with the new bank $i$ 's capital.

\subsubsection{Identification of banks that need a bail-in}

We identify banks that need a bail-in by assessing their capitalization conditions. In this paper, we choose one of the criteria listed below to investigate the effects of adopting bail-ins as a part of a resolution process. The first is related to the compliance with Basel III's capital requirements, while the second is a leverage ratio. According to the first criterion, bank $i$ must be bailed in if at least one of the conditions below is met: 


$$
\begin{aligned}
\frac{K_{i}^{C}(t)}{R W A_{i}(t)}<I^{C}, \\
\frac{K_{i}^{T 1}(t)}{R W A_{i}(t)}<I^{T 1}, \\
\frac{K_{i}^{T}(t)}{R W A_{i}(t)}<I^{T},
\end{aligned}
$$

in which $I^{C}, I^{T 1}$ and $I^{T}$ are capitalization indices related to the regulatory capital requirement ratios $F^{C}$ for Core Capital, $F^{T 1}$ for Tier1 Capital, and $F^{T}$ for Total Capital. We evaluate $R W A_{i}(t)$ using (9) and $K_{i}^{C}(t), K_{i}^{T 1}(t), K_{i}^{T}(t)$ using $(11)$. If at any iteration $t$ any of these indices is violated, then bank $i$ is resolved. These indices are exogenous to the model.

In our empirical exercises, we study the effectiveness of bail-ins assuming that they are triggered whenever a bank breaches any of the capital requirement parameters $I^{C}, I^{T 1}$ and $I^{T}$. In the next sections, we perform simulations considering that these parameters are the actual regulatory capital requirement ratios. Notwithstanding, this model permits simulating bail-ins for different parameter choices. This is useful for testing conditions in which banks are temporarily allowed to be less capitalized than required by regulation.

\subsubsection{Allocation of losses to liabilities}

If any of the restrictions (13) $-(15)$ is violated, then bank $i$ must be bailed in. There are two possibilities. In the first, if bank $i$ 's capital is sufficient to absorb the losses (Section 4.2.1), then we only assess whether it needs to be recapitalized as described in Section 4.2.4. If the capital is not sufficient, the reminiscent non-absorbed loss will be allocated to bail-inable liabilities of bank $i$. The remainder of this section assumes the second option.

The non-absorbed loss is allocated to debt holders according to the seniority of their claims. In this paper, debt seniority classes depend on the bank being a D-SIB ${ }^{24}$ Table 1 reports the seniority classes. Losses are absorbed from the lowest class 1 to the highest class 4 . This hierarchy segregates senior debt held by banks (class 2) or non-banks (class 3). Debt held by banks is bail-inable while that held by non-banks is not. The rationale behind this is to mitigate potential bank runs from depositors. Class 4 is not subject to bail-in.

We end up with three classes of bail-inable resources for D-SIBs and two classes for non-D-SIBs. To match layers, we aggregate liabilities of classes (2) and (3) of non-D-SIBs into the equivalent class 3 of D-SIBs.

Bank $i$ is able to absorb $W D_{i}^{s}(t)$ from its capital at iteration $t$, according to (10). The remaining non-absorbed part, i.e. $\Delta \varepsilon_{i}(t-1)-W D_{i}^{s}(t)$, is sequentially absorbed by the bail-inable liabilities following the seniority class 1 up to 4 as follows:

\footnotetext{
${ }^{24}$ We should note the definition of which banks and liability classes are subject to the bail-in process are at the discretion of the authorities and the domestic law.
} 
Table 1: Bail-inable $(B)$ and non-bail-inable (NB) debt instruments for D-SIBs and non-D-SIBs, from lower to higher seniority.

\begin{tabular}{lcc}
\hline \multirow{2}{*}{ Seniority classes } & \multicolumn{2}{c}{ Bank type } \\
1) subordinated/convertible debt instruments & D-SIB & Non-D-SIB \\
2) senior unsecured uninsured debt held by banks & B & B \\
3) senior unsecured uninsured debt held by non-banks & NB & NB \\
4) senior insured or secured debt & NB & NB \\
\hline
\end{tabular}

$$
W D_{i}^{c}(t)=\min \left[D_{i}^{c}(t-1), \Delta \varepsilon_{i}(t-1)-W D_{i}^{s}(t)-\sum_{l=1}^{c-1} W D_{i}^{l}(t)\right]
$$

for $c \in\{1, \ldots, 4\}$. The term $W D_{i}^{c}(t)$ represents the written-down amount of bail-inable liabilities at class $c$ from bank $i$ at iteration $t$. Note that subsequent seniority class are only eligible for the losses that junior classes could not fully absorb.

We need to adjust the liabilities of creditor bank counterparties of bank $i$ in view of the bail-in process. We do this process for each seniority class, each of which representing a layer in the multilayer exposures network. Analogously to the cross-holding network update in (12), we write down the debt proportionally to the amount that was subject to the bail-in because we consider that each debt holder in a given seniority class has the same priority as the others in the category.

Mathematically, we update the liability of seniority class $c$ of creditor bank $j$ to $i$ at iteration $t$ following the expression:

$$
L_{i j}^{c}(t)= \begin{cases}0, & \text { if } D_{i}^{c}(t-1)=0 \\ {\left[1-\frac{W D_{i}^{c}(t)}{D_{i}^{c}(t-1)}\right] L_{i j}^{c}(t-1),} & \text { otherwise }\end{cases}
$$

for $c \in\{1,2,3\}$. We do not adjust senior insured or secured liabilities (seniority class $c=4$ ) because in the case of a write-down, the creditor receives insurance or grabs the collateral that corresponds to the written-down liabilities, which offsets the losses he would incur.

After the write-down, the balance of debts in each seniority class $c$ is given by:

$$
D_{i}^{c}(t)=D_{i}^{c}(t-1)-W D_{i}^{c}(t)
$$

for $c \in\{1, \ldots, 4\}$.

If bank $i$ is a D-SIB and $W D_{i}(t)>D_{i}^{1}(t-1)+D_{i}^{2}(t-1)$ or if it is not a D-SIB and $W D_{i}(t)>$ 
$D_{i}^{1}(t-1)$, bank $i$ will be liquidated after the write-down of debts described above, following the process in Section 4.2.5.

\subsubsection{Recapitalization}

After absorbing losses, we impose banks need to be recapitalized above the regulatory requirements as a way to prevent further fluctuations of their capital levels. The recapitalization level is implemented using extra conversion of bail-inable liabilities into capital. Therefore, the bank not only needs bail-inable resources to withstand the write-downs (Section 4.2.3) but also recapitalization.

Local effect: We compute the bank $i$ 's need of capital $K_{i}^{R}$ from the target capitalization indexes given as parameters $I_{R}^{C}$, for Core Capital, $I_{R}^{T 1}$, for Tier 1 Capital, and $I_{R}^{T}$, for Total Capital. These parameters are usually set above the regulatory requirements, i.e., $I_{R}^{C}>F^{C}, I_{R}^{T 1}>F^{T 1}$, and $I_{R}^{T}>F^{T}$.

Define the following auxiliary function:

$$
V_{i}(I, K)=R W A_{i} \frac{I}{100}-K
$$

then the recapitalization of bank $i$ is:

$$
K_{i}^{R}=\max \left[V\left(I_{R}^{C}, K_{i}^{C}\right), V\left(I_{R}^{T 1}, K_{i}^{T 1}\right), V\left(I_{R}^{T}, K_{i}^{T}\right)\right]
$$

i.e. we perform the recapitalization in accordance with the index that is performing the worst.

The recapitalization will be successful only if $K_{i}^{R} \leq D_{i}^{1}(t)+D_{i}^{2}(t)$ in the case bank $i$ is D-SIB and $K_{i}^{R} \leq D_{i}^{1}(t)$, otherwise. If the bank does not have enough bail-inable resources to complete the recapitalization, then it will be liquidated following the process in Section 4.2 .5 .

The recapitalization rationale uses bail-inable resources and follows the previous strategy: we convert more junior bail-inable classes before reaching more senior classes. Debt conversion to shares is performed proportionally among debtors with the same seniority.

Given the recapitalization target level in (20), bank $i$ will have to convert bail-inable debt until such target is reached. Let $C D_{i}^{c}(t)$ be the amount converted in each seniority class $c \in\{1,2\}$. Then ${ }^{25}$

$$
\begin{aligned}
& C D_{i}^{1}(t)=\min \left(D_{i}^{1}(t), K_{i}^{R}\right), \\
& C D_{i}^{2}(t)=\min \left(D_{i}^{2}(t), K_{i}^{R}-C D_{i}^{1}(t)\right) .
\end{aligned}
$$

We also update the debt variables and the capitalization variables of bank $i$ as follows:

\footnotetext{
${ }^{25}$ Recall that $D_{i}^{2}(t)=0$ if bank $i$ is non-D-SIB.
} 


$$
\begin{aligned}
& D_{i}^{1}(t)=D_{i}^{1}(t)-C D_{i}^{1}(t), \\
& D_{i}^{2}(t)=D_{i}^{2}(t)-C D_{i}^{2}(t), \\
& e_{i}(t)=e_{i}(t)+K_{i}^{R}, \\
& K_{i}^{B}(t)=K_{i}^{B}(t)+K_{i}^{R}, \\
& K_{i}^{C}(t)=K_{i}^{C}(t)+K_{i}^{R}, \\
& K_{i}^{T 1}(t)=K_{i}^{T 1}(t)+K_{i}^{R}, \\
& K_{i}^{T}(t)=K_{i}^{T}(t)+K_{i}^{R} .
\end{aligned}
$$

Network effect: We need to update the balance sheet of banks $j$ that were holding assets against bank $i$ but had these assets converted to shares due to the recapitalization. For every affected bank $j$, we update its cross-holding shares to bank $i$ as follows:

$$
\begin{aligned}
& s_{i j}(t)=s_{i j}(t)+L_{i j}^{1}(t) F_{i}^{R 1}+L_{i j}^{2}(t) F_{i}^{R 2}, \\
& L_{i j}^{1}(t)=\left[1-F_{i}^{R 1}(t)\right] L_{i j}^{1}(t), \\
& L_{i j}^{2}(t)=\left[1-F_{i}^{R 2}(t)\right] L_{i j}^{2}(t),
\end{aligned}
$$

in which:

$$
F_{i}^{R_{c}}(t)= \begin{cases}1 & \text { if } D_{i}^{c}(t)=0 \\ C D_{i}^{c}(t) / D_{i}^{c}(t) & \text { otherwise }\end{cases}
$$

for $c \in\{1,2\}$.

\subsubsection{Liquidation of banks}

In this model, banks are liquidated if they cannot be successfully bailed in (loss absorption + recapitalization). The liquidation occurs after the write-down of claims. In the short term, liquidated banks cannot make any repayments as their assets are frozen in view of legal reasons. In this way, its network creditors $j$ have to readjust their loss provisions to consider a $100 \%$ loss. This corresponds to setting their claims to zero as follows:

$$
L_{i j}^{c}(t)=0,
$$

for $c \in\{1,2,3\}$. Correspondingly, we set to zero the shares that shareholder banks $j$ have to bank $i$ : 


$$
s_{i j}(t)=0 \text {. }
$$

After the equilibrium is reached, we segregate the liquidated banks' residual assets (computed after losses) from the banking system's total assets and use them for computing the assets for recovery. We compute them by subtracting senior insured or secured debt $D_{i}^{4}$ from the residual assets $A_{i}(t) . D_{i}^{4}$ corresponds roughly to the assets posted as collateral, which are not frozen and are grabbed by bank $i$ 's creditors as soon as it defaults or is liquidated. Henceforth, we consider these assets as the liquidation cost, that is, the loss imposed on society in the short term due to the bank liquidation. We compute bank $i$ 's liquidation costs $A_{i}^{R, B}$ as:

$$
A_{i}^{R, B}=\max \left[0, A_{i}(t)-D_{i}^{4}\right], \quad \text { for } i \in \mathscr{L},
$$

in which $\mathscr{L}$ is the set of banks liquidated during the resolution process.

Besides evaluating contagion losses that arise from write-downs during a bail-in or those related to a freeze in assets invested in liquidated banks, we also consider the short-term credit crunch that would occur due to the liquidation of a bank, taking as baseline the level of its lending immediately before liquidation. We consider computing the credit crunch from new loans of a bank before being liquidated is a proxy for the credit crunch prevented by a bail-in as we hypothesize a bail-in does not worsen the distress faced by a bank. We assume that, by improving its capitalization, a bail-in allows it to continue lending at roughly the same level, as the older loans are being repaid. Conversely, if a bank is liquidated, it will not be able to lend money, leading its borrowers to seek other credit relationships.

In the real world, the substitution of bank counterparts takes time, given that these borrowers need to search for and contact other banks and negotiate with them. In this paper, we assume a worstcase scenario, in which borrowers do not find adequate substitutes for these relationships in the shortterm. We focus on the short-term credit crunch considering in each unit of time, in our case, three months, the credit that would be granted by the bank that was liquidated will have to be supplied by the rest of the banking system. In other words, we measure credit crunch as a monetary flow during a time unit, instead of quantifying it on a fixed period, whose length would have to be assumed or measured somehow. We measure the credit crunch monetary flow over three months as this period is still considered short-term while reducing the variability of the monthly observations of the loans' time series. We compute the credit crunch that results from adopting this resolution process with a bail-in $C C_{s}^{B}$ starting from an initial scenario $s$ after the equilibrium has been reached:

$$
C C_{s}^{B}=\sum_{i \in \mathscr{L}} N C_{i}
$$


In the equation above, $N C_{i}$ is the sum of the new loans by bank $i$ in the last three months.

\subsubsection{Contagion losses}

We aggregate contagion losses experienced by bank $i$ in iteration $t$ into $\Delta \varepsilon_{i}^{t}$ as follows:

$$
\Delta \varepsilon_{i}(t)=\sum_{j \in \mathscr{B}}\left(s_{i j}(t-1)-s_{i j}(t)+\sum_{c=1}^{3}\left(L_{i j}^{c}(t-1)-L_{i j}^{c}(t)\right)\right) .
$$

Our algorithm runs until contagion losses settle down, i.e. when $\left|\Delta \varepsilon_{i}(t)\right|<\delta \ll 1, \forall i \in \mathscr{B}$, holds. Otherwise, we accumulate the losses as follows:

$$
\varepsilon_{i}(t+1)=\varepsilon_{i}(t)+\Delta \varepsilon_{i}(t)
$$

i.e. $\varepsilon_{i}(t+1)$ accumulates the losses up to the iteration $t+1$.

\subsection{Resolution process without a bail-in}

To disable bail-ins and simulate bank liquidations only, we simply assume that banks do not hold any bail-inable debt. We achieve this by removing all edges of the three-layer network representing the bail-inable exposures as follows: $L_{i j}^{1}(0)=L_{i j}^{2}(0)=L_{i j}^{3}(0)$. Just like the previous model, we do not include the class of least seniority into the contagion process as, in the case of default, the holder receives insurance or collateral.

\subsection{Systemic risk measurement}

Our measure of the systemic risk of the banking network is based on an adaptation of Bardoscia et al. (2015)'s differential DebtRank. We provide details of this measure in Appendix B. Here, we focus on the performed adaptations.

We use the differential DebtRank to measure the systemic risk just after imposing an initial loss (shock) to the banking system and after the resolution process has ended. During the resolution process, the liquidated banks are removed from the network. This generates two opposite effects: on the one hand, their creditors are weakened; on the other hand, the exit of a fragile bank contributes to strengthening the whole system.

We compute the systemic risk measure $R_{D D R}$ of the entire banking system conditioned on the initial stress scenario vector $\boldsymbol{h}^{s}(0)$. We take each element $\boldsymbol{h}_{j}^{s}(0) \in[0,1]$ as the shares of banks $j$ 's capital buffer that were lost during the stress scenario $s$. Mathematically: 


$$
R_{D D R}\left(\boldsymbol{h}^{s}(0)\right)=\sum_{i \in \mathscr{B}} D D R\left(\boldsymbol{h}_{i}^{s}(0)\right) \varphi_{i}
$$

with:

$$
\begin{aligned}
& \boldsymbol{h}_{\boldsymbol{i}}^{\boldsymbol{s}}(0)=\left[\boldsymbol{h}_{i j}^{\boldsymbol{s}}(0)\right]_{j \in \mathscr{B}}, \text { and } \\
& \boldsymbol{h}_{i j}^{\boldsymbol{s}}= \begin{cases}1 & \text { if } j=i, \\
h_{j}^{s}(0) & \text { otherwise. }\end{cases}
\end{aligned}
$$

Equation (31) differs from (B.6) as follows. In (B.6), we must define an initial stress vector in which there is a shock, as the methodology requires an initial shock for detecting risk. Thus, we compute $D D R(\cdot)$ for an initial stress scenario vector $\boldsymbol{h}(0)$ in which a single bank $i$ is in default. In turn, in $(31)$, we compute $R_{D D R}$ by weighing the $D D R(\cdot)$ s computed for each bank in the system by the bank's economic value. The computations of $D D R(\cdot)$ use as parameters the initial stress scenario vectors $\boldsymbol{h}_{i}^{s}(0)$. This vector is similar to the $\boldsymbol{h}(0)$ vector, defined in (B.6). However, $\boldsymbol{h}_{i}^{\boldsymbol{s}}(0)$ is given by the initial stress scenario $\boldsymbol{h}^{s}(0)$, but imposing that bank $i$ is in default, as described in (32). To compute $R_{D D R}$ just after the banks have received a shock, we form $\boldsymbol{h}_{i}^{s}(0)$ from the shock scenario. When computing $R_{D D R}$ after the end of the resolution process, we set $\boldsymbol{h}_{i}^{\boldsymbol{s}}(0)$ to zero and compute the vulnerability matrix $\boldsymbol{V}$ in $\mathrm{B} .1$ using the capital buffers and exposures from the end of the process.

\section{Data}

Data is confidential and comes from the BCB. We collect three types of data: (i) supervisory information of the banking system, (ii) bank accounting information (Accounting Plan of the National Financial System Institutions database) and loan-level credit operations to firms (Brazilian Credit Registry). We use the first two blocks of information to simulate the behavior of financial contagion with and without bail-in in the banking system. We employ credit operations data to evaluate how the real sector would suffer from a credit crunch.

We consider bank conglomerates and individual banking institutions. The Brazilian banking system contains universal, commercial, investment and federal savings banks. All collected data refers to end-of-month information in December 2016, except the credit register data, in which we use the period from October 2016 to December 2016 to evaluate potential credit crunches. Bank-level information comprises bank prudential segment, capitalization levels, total assets and liabilities. Network data contains all bank-bank bilateral exposures, including those of senior unsecured debt issued by these banks. 
The criteria for identifying bank prudential segments are defined by the BCB's Resolution 4.553/201726. All banks in the sample belong to segments S1-S4. We do not study G-SIBs, even as subsidiaries ${ }^{27}$ as we do not perform analyses of cross-border effects. The banking system has five D-SIBs that belong to segment S1.

Regarding the network of bilateral exposures, we consider a directed and weighted three-layer graph, in which each layer corresponds to a seniority class of bail-inable resources (see Section 4.2.3). Vertices denote banks and links between a pair of banks $(i, j)$ are totals of bank $i$ 's exposures to bank $j$ 's debt of the corresponding seniority class. We aggregate these exposures regardless of the instrument type or time to maturity, given that the methodology only uses information on total exposures. Additionally, we do not net out exposures among pairs of banks as in the resolution process liquidated banks are yet entitled to their claims.

We collect data of credit operations granted to firms from the Brazilian Credit Registry. This database provides monthly granular data at the last day of each month. Our data comprises operation ID, date, type of credit, lender bank and some characteristics of the borrower, such as its economic sector. For each operation and date, there is also information on the outstanding credit and a summarized projected cashflow 3, 6, 9, 12, 18, 24, 36 months ahead. We also can identify the new loans by finding operation IDs that did not appear before the month/year under analysis. We aggregate these new loans by lending bank over the previous three months to perform short-term credit crunch estimates as described in previous sections.

To evaluate the effect of credit crunches on different economic sectors, we match borrower information of the Credit Registry with data from the Receita Federal — the Brazilian IRS — to extract the borrower's economic sector, encoded in the National Classification of Economic Activities 28 (CNAE). We also analyze the role of the type of credit in the credit crunch.

Table 2 summarizes information broken down by each segment. Five out of the six banks in segment S1 are D-SIBs. The segment also concentrates $73 \%$ of the banking system total assets. The S1 segment also holds $69 \%$ of the entire shareholders' equity in the banking system and total $63 \%$ of bail-inable debt. In comparison, the segment S2 has a share of total bail-inable debt in the banking system about twice that of their shareholders' equity. The ratio between total exposures to bail-inable

\footnotetext{
${ }^{26}$ BCB's Resolution 4.553/2017 defines bank prudential segmentation categories as follows:

(S1) Universal banks, commercial banks, investment banks, foreign exchange banks and federal savings banks that have either of the following characteristics: (i) size equal to or greater than 10\% (Total Exposure/Gross Domestic Product); or (ii) relevant international activity (foreign assets are equal to or greater than US\$ 10 billion).

(S2) (i) - Universal banks, commercial banks, investment banks, foreign exchange banks and federal savings banks whose size is less than $10 \%$ and equal to or greater than $1 \%$ of GDP; and (ii) other institutions whose size is equal to or greater than $1 \%$ of GDP.

(S3) Institutions whose size is less than $1 \%$ of GDP and equal to or greater than $0.1 \%$ of GDP.

(S4) Institutions whose size is less than $0.1 \%$ of GDP.

(S5) (i) Institutions whose size is less than $0.1 \%$ of GDP and that use an optional simplified methodology to calculate the requirements of regulatory capital (Patrimônio de Referência - PR), Tier I Capital and Core Capital, except for multiple banks, commercial banks, investment banks, foreign exchange banks and federal saving banks; and (ii) Institutions that are not required to calculate $\mathrm{PR}$.

${ }^{27}$ Brazil hosts a single G-SIB subsidiary with significant operation in its territory, which is also classified as a D-SIB.

${ }^{28}$ Compliant with the International Standard Industrial Classification of All Economic Activities, Rev. 4, from the United Nations Statistics Division.
} 
Table 2: Banking system data aggregated by bank prudential segments in December, 2016 $(R \$ B n)$.

\begin{tabular}{lrrrrr}
\hline & S1 & S2 & S3 & S4 & Total \\
\hline Number of banks & 6 & 7 & 36 & 82 & 131 \\
Total assets & $5,748.06$ & $1,358.43$ & 588.97 & 135.34 & $7,830.80$ \\
Total liabilities & $5,335.91$ & $1,263.50$ & 519.37 & 111.81 & $7,230.60$ \\
Shareholders' equity & 412.15 & 94.93 & 69.60 & 23.53 & 600.20 \\
Bail-inable debt & 505.83 & 273.09 & 14.25 & 0.99 & 794.16 \\
Bail-inable debt to banks & 216.00 & 0.00 & 0.00 & 0.02 & 216.03 \\
Non-bail-inable debt & $4,830.08$ & 990.41 & 505.12 & 110.82 & $6,436.43$ \\
Interbank exposures & 66.70 & 267.18 & 17.68 & 6.53 & 358.08 \\
Exposures to bail-inable debt & 28.46 & 177.95 & 6.51 & 3.12 & 216.03 \\
New credit to firms (3M) & 199.37 & 36.77 & 39.84 & 17.08 & 293.06 \\
Outstanding credit to firms & $2,762.15$ & $1,223.79$ & 373.34 & 124.76 & $4,484.05$ \\
\hline
\end{tabular}

debt and total shareholders' equity is $36 \%$, suggesting that shareholder's equity largely surpasses bailinable debt as means of loss absorption.

Table 3 shows bail-inable debt shares by bank segmentation. For segments S2-S4, about all bailinable debt issued is held outside the banking system, which drive contagion effects related to bail-in write-downs away from the banking system. Bail-inable debt held by the banking system is primarily issued by S1 banks. Banks from the $\mathrm{S} 2$ segment are the main holders of these resources, which makes them the most vulnerable to bail-in write-downs related to $\mathrm{S} 1$ banks. This is confirmed by the shares of these resources held by individual S2 banks compared to their equities shown in Figure $1 \mathrm{~d}$.

Table 3: Bail-inable debt participations by bank segmentation in December, $2016(\%)$.

\begin{tabular}{lrrrrr}
\hline & \multicolumn{7}{c}{ Segment } \\
& S1 & S2 & S3 & S4 & Total \\
\hline Bail-inable debt issued & 63.69 & 34.39 & 1.79 & 0.12 & 100.00 \\
Bail-inable debt to banks & 99.99 & 0.00 & 0.00 & 0.01 & 100.00 \\
Bail-inable debt held & 13.17 & 82.37 & 3.01 & 1.44 & 100.00 \\
\hline
\end{tabular}

Table 4 shows the intersegment bail-inable debt exposures in more detail divided into seniority classes. Almost all of the lower seniority debt is held by non-banks regardless of the issuer segment. The senior bail-inable debt is issued exclusively by D-SIBs and held mostly by S2-segment banks. To summarize, the allocation of bail-inable instruments within the Brazilian banking system is such that losses originated from bail-ins mostly induce small contagion risk among banks as they are driven to non-banks in most cases. Even when banks are exposed to bail-inable instruments, these are of higher seniority, and therefore are the last to absorb losses when needed.

While Tables 2,4 show segment aggregates, Figure 1 displays box plot ${ }^{29}$ representing distri-

\footnotetext{
${ }^{29}$ In the box plots shown in this paper, we adopt the following conventions: the two adjacent boxes represent, from the
} 
Table 4: Bail-in instruments allocation - issuer x holder in December, 2016 (R\$ Bn).

\begin{tabular}{|c|c|c|c|c|c|c|c|c|}
\hline \multirow[b]{2}{*}{ Issuer } & \multirow[b]{2}{*}{ Type } & \multicolumn{4}{|c|}{ Holder } & \multirow[b]{2}{*}{ Banks } & \multirow[b]{2}{*}{ Non-banks } & \multirow[b]{2}{*}{ Total } \\
\hline & & $\mathrm{S} 1$ & S2 & $\mathrm{S} 3$ & S4 & & & \\
\hline \multirow[t]{2}{*}{$\mathrm{S} 1$} & Sub/Conv & 0.00 & 0.00 & 0.00 & 0.00 & 0.01 & 289.83 & 289.84 \\
\hline & Senior & 28.46 & 177.92 & 6.50 & 3.11 & 216.00 & 0.00 & 216.00 \\
\hline \multirow[t]{2}{*}{$\mathrm{S} 2$} & Sub/Conv & 0.00 & 0.00 & 0.00 & 0.00 & 0.00 & 273.09 & 273.09 \\
\hline & Senior & 0.00 & 0.00 & 0.00 & 0.00 & 0.00 & 0.00 & 0.00 \\
\hline \multirow[t]{2}{*}{$\mathrm{S} 3$} & Sub/Conv & 0.00 & 0.00 & 0.00 & 0.00 & 0.00 & 14.25 & 14.25 \\
\hline & Senior & 0.00 & 0.00 & 0.00 & 0.00 & 0.00 & 0.00 & 0.00 \\
\hline \multirow[t]{2}{*}{$\mathrm{S} 4$} & Sub/Conv & 0.00 & 0.02 & 0.00 & 0.00 & 0.02 & 0.97 & 0.99 \\
\hline & Senior & 0.00 & 0.00 & 0.00 & 0.00 & 0.00 & 0.00 & 0.00 \\
\hline \multicolumn{2}{|c|}{ Total Sub/Conv } & 0.00 & 0.02 & 0.00 & 0.00 & 0.03 & 578.14 & 578.16 \\
\hline \multicolumn{2}{|c|}{ Total Senior } & 28.46 & 177.92 & 6.50 & 3.11 & 216.00 & 0.00 & 216.00 \\
\hline \multicolumn{2}{|l|}{ Total } & 28.46 & 177.95 & 6.51 & 3.12 & 216.03 & 578.14 & 794.16 \\
\hline
\end{tabular}

butions of bail-inable instruments for individual banks in each segment as a share of the banks' total assets and shareholders' equity. Figure 1(a) shows that, for S1 banks, the share of issued instruments to their total assets is higher than those of banks from the other segments. A reason for this is D-SIBs are allowed to use senior uninsured unsecured debt instruments held by other banks. These instruments represent roughly $43 \%$ of the total bail-inable instruments issued by these banks (see Table 4). Most of the S2 banks issue bail-inable instruments, whereas most of the S3 and S4 banks do not issue these instruments. When it comes to bank held issued instruments, Figures 1(b) and 1(c) display similar information, differing in the denominator of the ratio. Bank held bail-inable instruments are mostly senior debt issued by S1 banks. Some of them have issued more than the total of their equities. From the point-of-view of holders of these instruments, Figure 11(d) shows each of the segments has banks that are remarkably vulnerable to the write-down of these exposures, which may amount to more than $50 \%$ of their shareholders' equity.

Figure 2 displays distributions of capitalization data of individual banks in each segment according to two criteria: a regulatory-related criterium (total capital ratio), and a simplified criterium (equity ratio). Figure 2(a) shows distributions of total capital (Tier1 + Tier2 capitals) to risk-weighted assets. Banks from S1 and S2 segments have about the same dispersion of capital ratios while S3 and S4 banks have a much higher dispersion in these figures. There is an S4 bank with a negative capital ratio which, however, has positive shareholders' equity. Figure 2(b) shows the distributions of ratios of equity to total assets for individual banks in each segment. Although there is an S1 bank with an equity ratio of little more than $2 \%$, in general, the S1 banks have a higher equity ratio than those in segment S2. S3 and $\mathrm{S} 4$ have, in general, much higher equity ratios, with 10 banks with more than $60 \%$. These banks will not default if they suffer losses related to exposures to bail-inable debt, which, from Figure 1(d), do not exceed $50 \%$ of equity.

bottom up, the 25th, 50th and 75th percentiles of the sample. The distance between the 25th and 50th, and between the 50th and 75th percentiles are the interquartile ranges. The whiskers are lines extending from below and above the 25th and 75th percentiles, with a length of 1.5 times the interquartile ranges. Observations beyond the whisker length are marked as outliers by a red "plus" sign. 
Total issued $\mathrm{BI} /$ Issuer assets

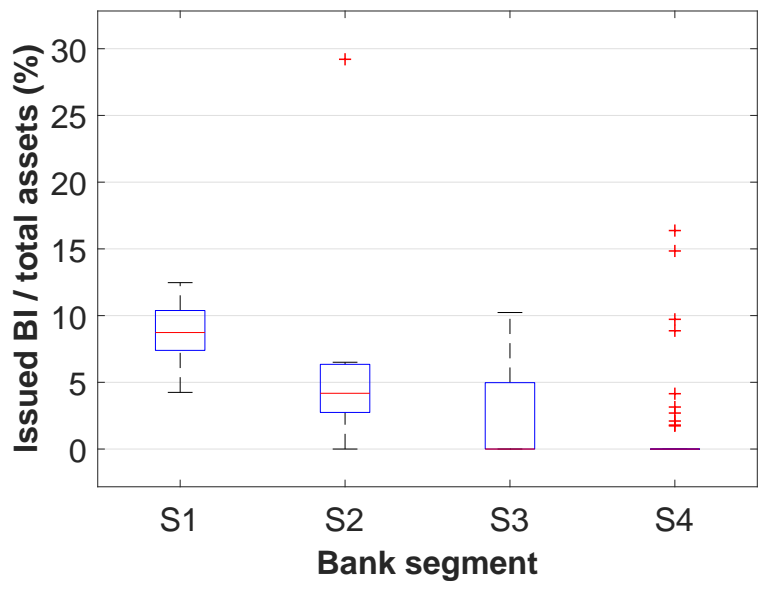

(a)

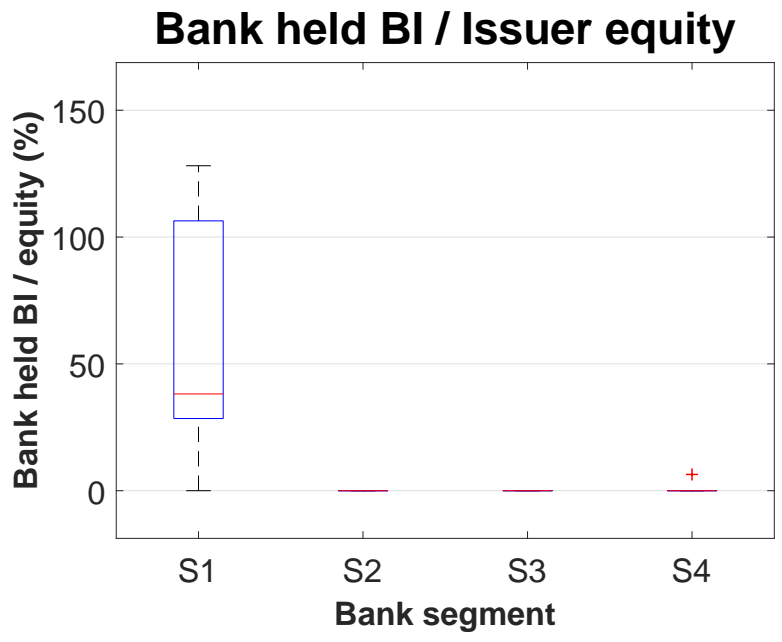

(c)

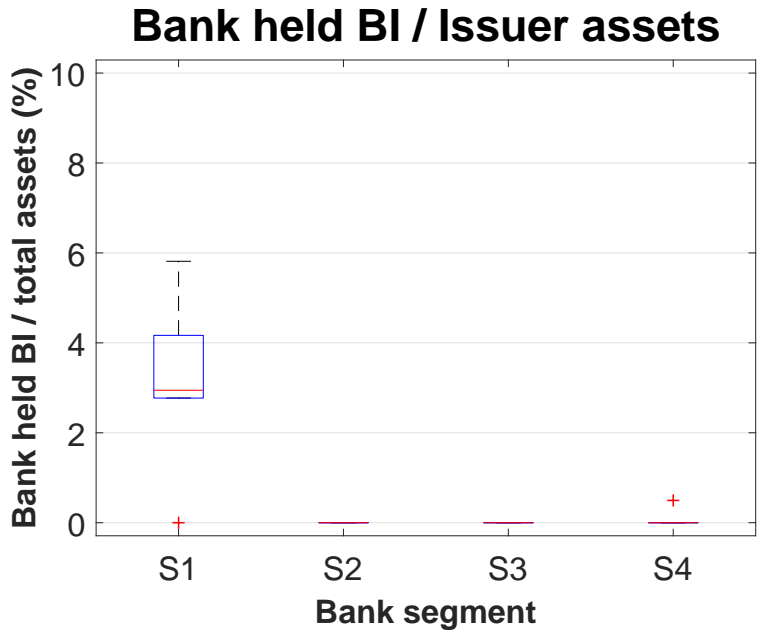

(b)

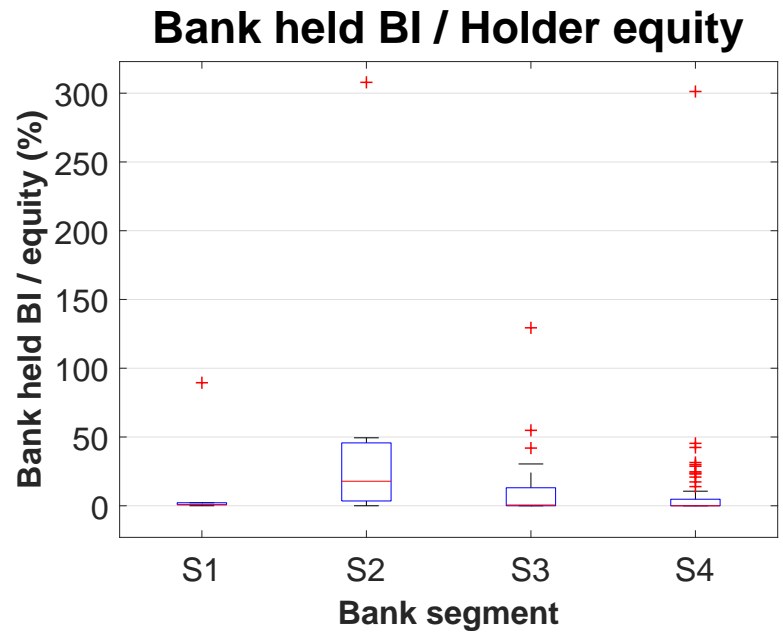

(d)

Figure 1: Boxplots of bail-inable instruments (BI) issued or held by banks in each segment in December, 2016. Figure (a) shows distributions, in each segment, of the total issuance of bail-in instruments that are held by banks or non-banks, as a share of the issuer's total assets. Figure (b) shows this distribution considering shares to total assets of issued instruments that are held by banks. Figure (c) shows the distributions of the same issued instruments considered in (b), but compute the ratios to the issuer bank's equity. Finally, Figure $(d)$ looks at the perspective of the holder banks, taking the totals of bail-in instruments held by the banks belonging to each segment, as a share of their equities.

Figure 3.a) portrays the network of the Brazilian interbank market in December 2016. We represent financial institutions as vertices and edges denote exposures among them. Edge boldness is proportional to the exposure value (amount lent). We depict bank control in different colors and bank prudential segments in different shapes. We observe a core-periphery structure in the network, in which the core comprises all S1 banks and a state-owned S2 bank ${ }^{30}$ In addition, the largest exposures are within the core. The periphery is composed mostly of S3 and S4 banks. In turn, Figure 3 (b) shows the network of exposures to bail-inable debt. This network represents two seniority classes of bail-inable debt: subordinated/convertible debt and senior uninsured unsecured debt. Almost all exposures are related to bail-inable senior uninsured unsecured debt 31 . Given that only D-SIBs can use this class of bail-inable instruments, the figure shows the non-D-SIBs exposed to these D-SIBS (they receive the

\footnotetext{
${ }^{30}$ Such network topology is common across different jurisdictions. Similar findings are also reported in Silva et al. (2016) for Brazil, in't Veld and van Lelyveld (2014) for the Netherlands and Fricke and Lux (2015) for Italy, among others.

${ }^{31}$ There are only three disconnected edges representing (small) exposures to subordinated/ convertible debt.
} 


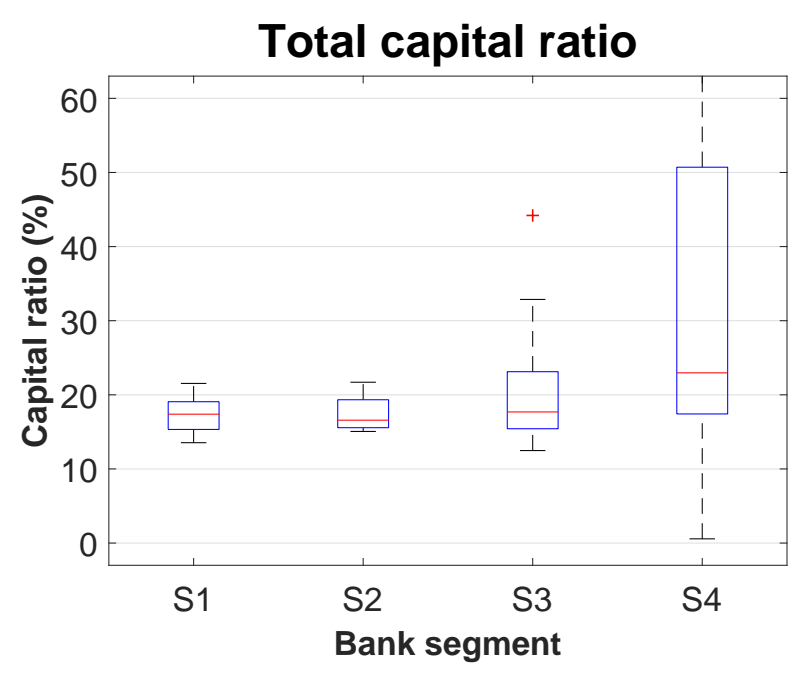

(a)

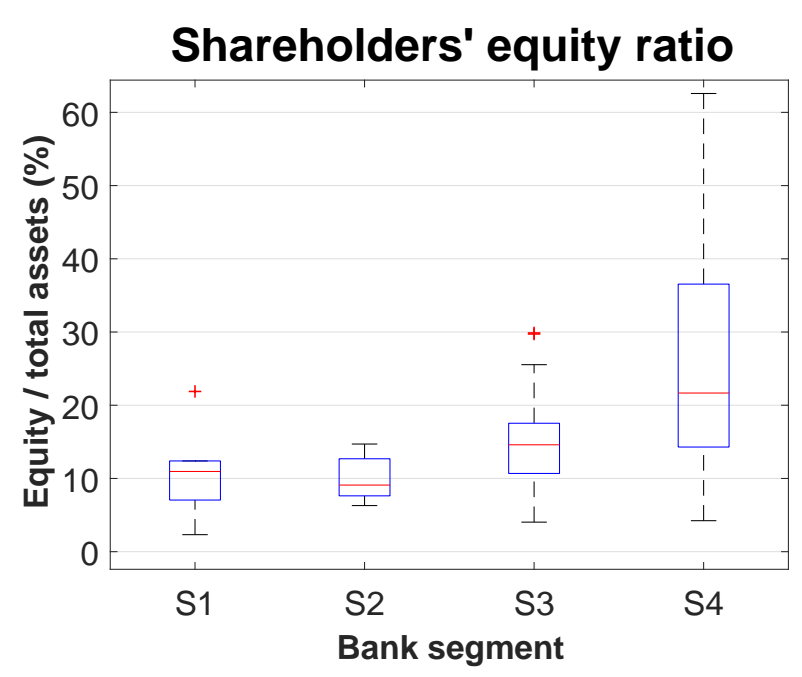

(b)

Figure 2: Boxplots of bank capitalizations for each segment in December, 2016. Figure (a) shows distributions of total capital ratios, and (b), distributions of shareholder's equity ratios. In Figure (a), for segment S4, there is one bank with capital ratio below zero (-36.3) and 17 banks with capital ratio above 60. The upper whisker is at 87.22 and the maximum, at 251.52. In Figure (b), in the S4 boxplot, there are 9 banks with shareholder's equity ratio above the upper whisker, with maximum at 96.93 .

arrowheads from the other banks).

Table 5 reports network metrics for the same interbank networks. In the top section of the table, we observe S1 banks have the largest in- and out-degrees, because they intermediate most of the operations within the interbank market. In addition, they are more diversified in their lending portfolios inside such market (45.3 counterparts on average) than their funding portfolios (29.3 counterparts on average). In terms of volume, in contrast, S1 banks get more funded than lend to other counterparts. On average, for each Brazilian Real lent to other bank counterpart, an average S1 bank gets funded with 3.31 Brazilian Reais within the interbank market. S2 banks have an opposite perspective, investing more in other bank counterparts than being funded. S1 banks are the most central banks, mostly because they have larger degree and intermediate financial operations, as pointed by the PageRank, betweenness, and closeness centrality measures. We also evaluate global network measures and find a network density of $6 \%$, showing that the Brazilian interbank network is very sparse, and an assortativity of -0.37 , suggesting a disassortative mixing pattern among financial institutions ${ }^{32}$ The bottom section of the table shows network metrics for senior uninsured unsecured debt issued by D-SIBs. We do not include the three small exposures to subordinated/convertible bail-inable debt in this table. From this table, we (expectedly) see that only S1 banks issue this type of bail-inable debt (D-SIBs are S1 banks). Besides, in the S1 segment, almost all of the unsecured interbank exposures are bail-inable. The table also shows segment S2 banks are the most exposed to this class of bail-inable debt, although they will not propagate losses in case they are successfully bailed in, as shown by their betweenness being equal to zero.

\footnotetext{
${ }^{32} \mathrm{~A}$ disassortative mixing pattern suggests that large banks tend to connect more to small banks, which is expected in a network with a well-defined core-periphery structure.
} 


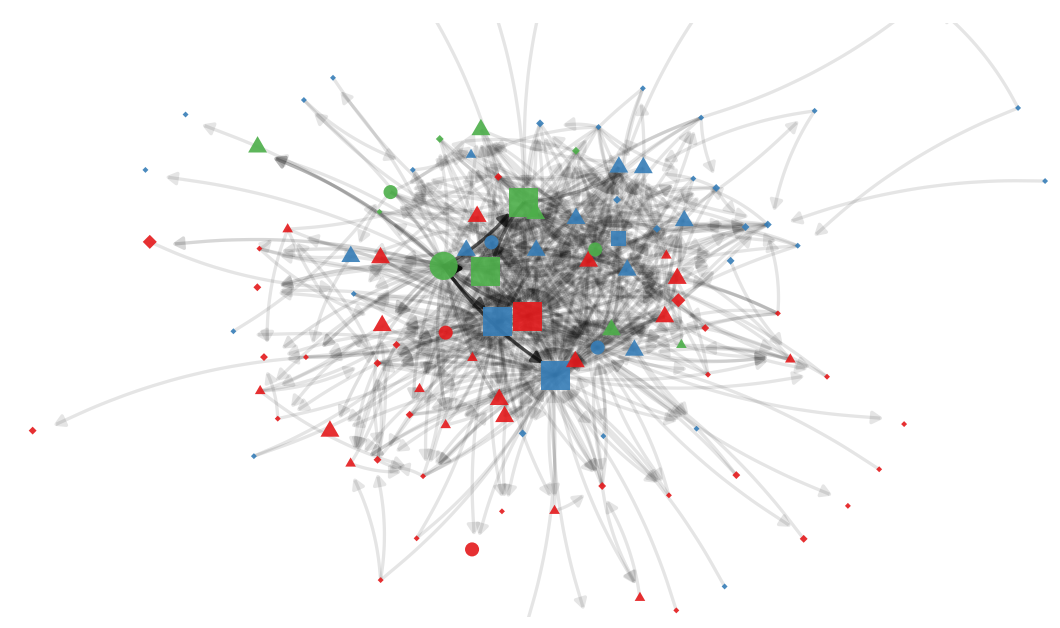

(a)

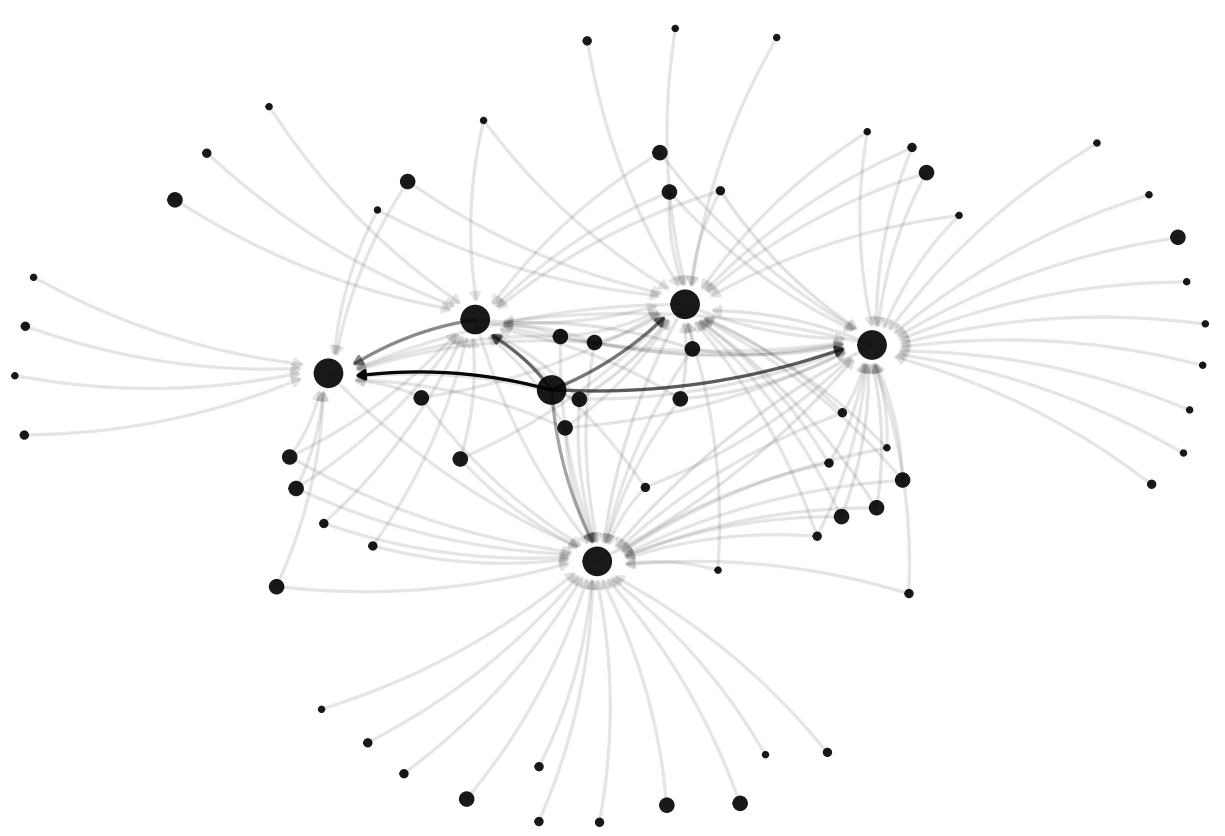

(b)

Figure 3: Network topology of the Brazilian interbank market in December 2016. Figure (a) shows unsecured interbank exposures, while Figure (b) shows exposures to bail-inable debt. Arrowheads point at the borrowers. Edge boldness is proportional to the exposure value (amount lent), and node size is proportional to total assets. We plot the giant component exposures and exposures larger than a hundred thousands Brazilian reais. Bank control types have these colors: green (state-owned), blue (private domestic) and red (foreign). Shapes identify bank prudential segments: square (S1), circle $(S 2)$, triangle (S3) and diamond (S4). In Figure (b), we do not show banks' control types and prudential segments. 
Table 5: Network metrics of the Brazilian interbank market in December 2016, for the networks of all unsecured interbank exposures and of bail-inable debt interbank exposures. The table reports strictly local and mixed network measures broken down by prudential segments. We normalize PageRank, betweenness, clustering coefficient and closeness measures. The first number is the average value followed by the standard deviation in parentheses. $N$ represents the number of banks in each prudential segment.

\begin{tabular}{lcccc}
\hline & Unsecured Interbank Exposures & & \\
Prudential Segment & $\mathrm{S} 1$ & $\mathrm{~S} 2$ & $\mathrm{~S} 3$ & $\mathrm{~S} 4$ \\
& $(N=6)$ & $(N=7)$ & $(N=35)$ & $(N=78)$ \\
\hline In-degree & $29.3(12.1)$ & $15.0(11.5)$ & $9.91(6.16)$ & $3.53(2.83)$ \\
Out-degree & $45.3(31.8)$ & $20.9(19.0)$ & $7.91(7.63)$ & $2.67(3.23)$ \\
In-strength (R\$ Bn) & $36.7(25.9)$ & $3.25(2.67)$ & $2.50(3.52)$ & $0.35(0.89)$ \\
Out-strength (R \$ Bn) & $11.1(13.8)$ & $38.2(94.3)$ & $0.51(0.89)$ & $0.08(0.26)$ \\
PageRank & $0.60(0.28)$ & $0.19(0.15)$ & $0.14(0.13)$ & $0.05(0.05)$ \\
Betweenness & $0.55(0.40)$ & $0.08(0.10)$ & $0.08(0.15)$ & $0.02(0.08)$ \\
Clustering coefficient & $0.27(0.06)$ & $0.40(0.27)$ & $0.42(0.18)$ & $0.51(0.28)$ \\
Closeness & $1.00(0.00)$ & $0.98(0.04)$ & $0.88(0.25)$ & $0.90(0.22)$ \\
\hline & Bail-inable Debt Interbank Exposures & & \\
Prudential Segment & $\mathrm{S} 1$ & $\mathrm{~S} 2$ & $\mathrm{~S} 3$ & $\mathrm{~S} 4$ \\
& $(N=6)$ & $(N=6)$ & $(N=26)$ & $(N=36)$ \\
\hline In-degree & $26.7(16.5)$ & $0.00(0.00)$ & $0.00(0.00)$ & $0.00(0.00)$ \\
Out-degree & $3.00(1.26)$ & $3.83(1.60)$ & $2.31(1.26)$ & $1.64(0.80)$ \\
In-strength (R\$ Bn) & $36.0(27.0)$ & $0.00(0.00)$ & $0.00(0.00)$ & $0.00(0.00)$ \\
Out-degree & $4.74(9.62)$ & $29.7(68.7)$ & $0.25(0.44)$ & $0.09(0.25)$ \\
PageRank & $0.43(0.44)$ & $0.01(0.00)$ & $0.01(0.00)$ & $0.01(0.00)$ \\
Betweenness & $0.54(0.36)$ & $0.00(0.00)$ & $0.00(0.00)$ & $0.00(0.00)$ \\
Clustering coefficient & $0.18(0.16)$ & $0.85(0.05)$ & $0.84(0.18)$ & $0.89(0.17)$ \\
\hline
\end{tabular}




\section{Analyses and Results}

We discuss the empirical contributions of the paper in this section. We first simulate large shocks and check the bail-in efficiency in mitigating losses under these extreme scenarios. Then, we focus on a subset of banks that can perform successful bail-in to analyze the benefits for society and the effects of credit crunch reduction to firms when we introduce bail-ins. Finally, we provide a toolbox for helping the Resolution Authority in evaluating costs and benefits of enacting hypothetical minimum requirements of bail-inable instruments for banks.

\subsection{Bail-in performance under extreme scenarios (large shocks)}

In this section, we simulate idiosyncratic and large shocks targeting each of the 131 banks in the Brazilian banking system. These shocks serve as inputs to our model. We then compare loss outcomes when we bail-in non-compliant banks instead of liquidating them upfront in these extreme scenarios. Our purpose is to test to what extent the introduction of a bail-in resolution mechanism mitigates losses.

In these simulations, bail-in (or liquidation) is triggered when a bank becomes non-compliant with Basel III's capital requirements (see Section 4.2.2). We set the recapitalization target pursued during bail-ins as the median of the peer group banks-i.e. those belonging to the same segment of the bank undergoing bail-in-as shown in Table 6. We provide further details on bail-in assessment variables and contagion variables in Appendix $\mathrm{C}$.

We construct idiosyncratic and large shocks for each bank in such a way to wipe out the totality of its assets, excluding cash equivalent holdings $\left(A_{i}^{C e q}\right)$ and bank reserves $\left(R B_{i}\right)$, i.e.:

$$
\Delta \varepsilon_{i}^{0}=A_{i}-R B_{i}-A_{i}^{C e q}
$$

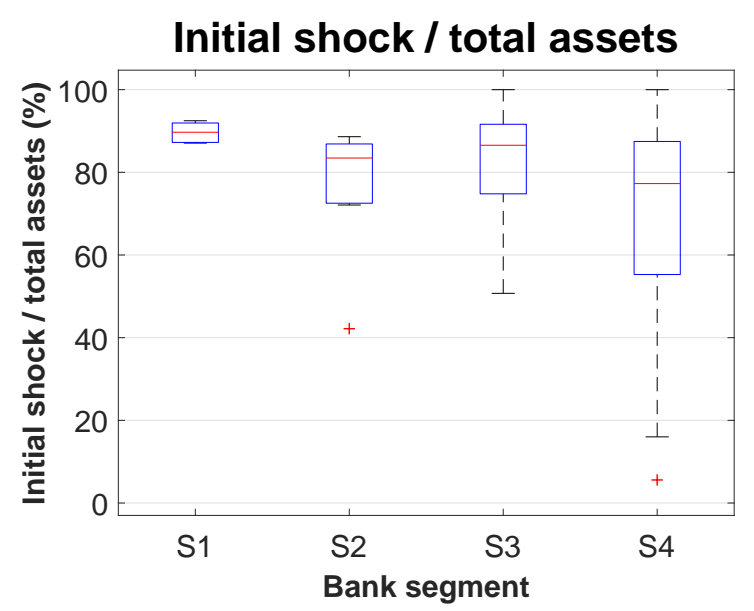

Figure 4: Distributions of the ratios of the initial shock magnitude applied to each bank to its corresponding total assets. We report distributions for each bank prudential segment.

The bank-specific shock in (33) is large enough to ensure that each targeted bank gets liquidated and generates the largest potential contagion losses. To get a sense of the magnitude of these bank- 
specific shocks, Figure 4 portrays the shock magnitude relatively to the bank total assets (ratios) broken down by bank prudential segments. They are far above shareholders' equity ratios shown in Figure $2(b)$.

Table 6: Capitalization indices that indicate when to start off a bail-in and the target level to be attained after recapitalization. We report results for each bank prudential segment.

\begin{tabular}{lcccc}
\hline Condition & Bank segment & $I^{C}$ & $I^{T 1}$ & $I^{T}$ \\
\hline Initial & All & 4.5 & 6 & 10.5 \\
\cline { 3 - 5 } & & $I_{R}^{C}$ & $I_{R}^{T 1}$ & $I_{R}^{T}$ \\
\cline { 3 - 5 } Final & $\mathrm{S} 1$ & 12.13 & 13.97 & 17.39 \\
& $\mathrm{~S} 2$ & 13.66 & 13.66 & 16.58 \\
& $\mathrm{~S} 3$ & 15.99 & 16.08 & 17.65 \\
& $\mathrm{~S} 4$ & 21.28 & 21.28 & 22.09 \\
\hline$I^{C}, I^{T 1}$ and $I^{T}$ are the capitalization indexes that trigger bail-ins for Core \\
Capital, Tier 1 Capital and Total Capital. The subscript $R$ in $I_{R}^{C}, I_{R}^{T 1}$ and \\
$I_{R}^{T}$ indicates that these are target recapitalization indexes.
\end{tabular}

Figures 5 and 6 display the results for our simulations when we apply the large shock in $(33)$ in each bank in an independent manner. To understand whether banks hold enough bail-inable resources for a successful bail-in, Figure 5(a) shows the bank-specific ratio of available bail-inable resources (Equation (C.1) to the minimum amount of these resources required for a successful bail-in (Equation (C.3)). Most banks from segments S3 and S4 have no available bail-inable resources (see Figure 1(a)). We find that 13 banks have availability ratios above one, meaning that they have the minimum amount of bail-inable instruments to be converted into capital during a bail-in. These banks are: all S1, two S2, four S3 and one S4.

Figure 5(b) compares the maximum losses that each bank can withstand without triggering a bail-in, given by Equation (C.2), with the maximum losses that the bank can bear if it can be bailed in, given by Equations (C.6) or (C.7). The 13 banks identified in the previous analysis are above the 45-degree line. For the larger banks, the additional loss-absorbing capability provided by a bail-in reaches tens of $\mathrm{R} \$$ billions.

Figure 5(c) compares the contagion losses experienced by the banking system when we apply the large shocks in (33). In the exercise, we simulate our model with resolution processes that include a bail-in (Equation (C.8) ) with those that do not include. In this figure, as in Figures 5(e) and 5(f), we plot the difference between the amounts computed for each scenario and for the scenario in which no banks receive a shock 5 . Figure 5(c) shows that bailing in banks has little effect on the magnitude of the contagion process triggered by these scenarios. We explain this effect as follows.

In these scenarios, the bank that receives the initial shock is liquidated and, in the short term,

\footnotetext{
${ }^{33}$ This procedure intends to isolate the effect from the shock that is part of the scenario from the effect from the original state of the banking system. The simulation of the scenario representing the original state of the system (no shock) results in two liquidated banks and one successfully bailed in (in resolution processes with bail-ins,) or in three liquidated banks (process without bail-ins). In the simulations, these outcomes are superimposed on those from the simulations of shock scenarios.
} 


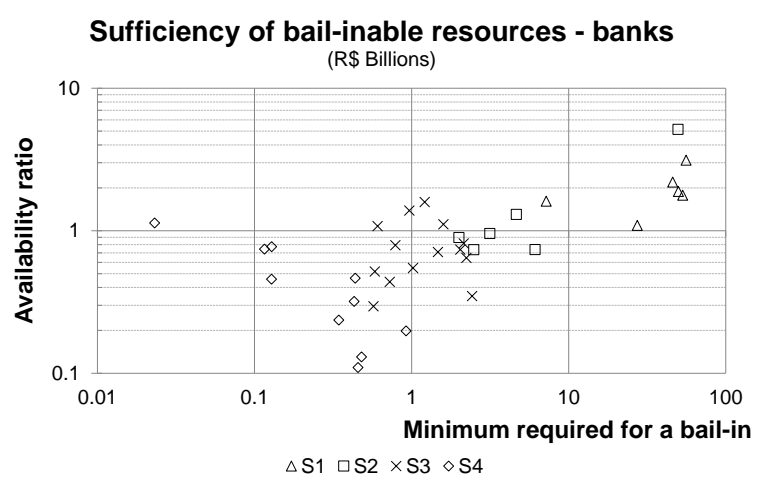

(a)

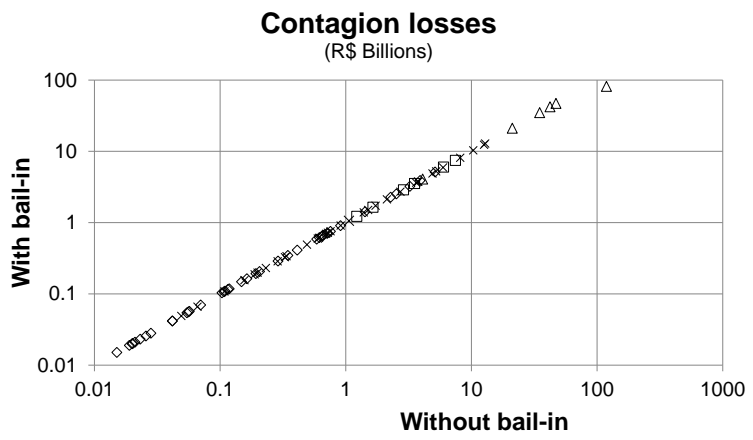

$\triangle \mathrm{S} 1 \square \mathrm{S} 2 \times \mathrm{S} 3 \diamond \mathrm{S} 4$

(c)

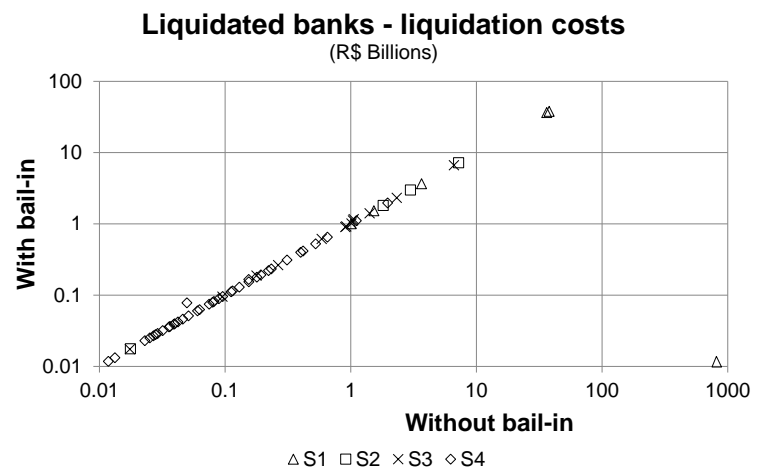

(e)

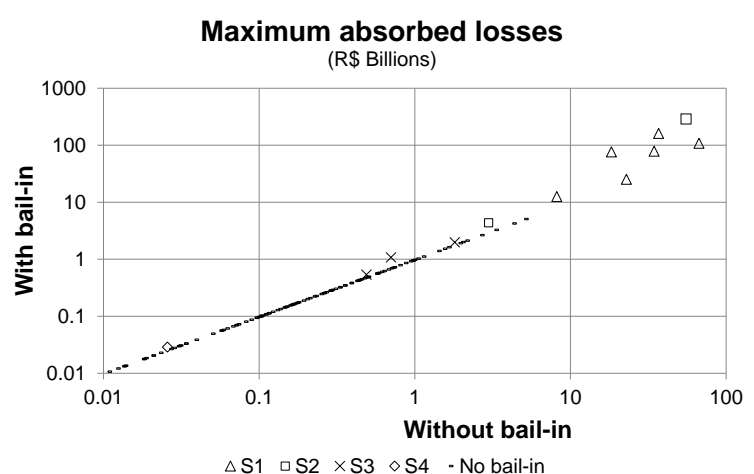

(b)

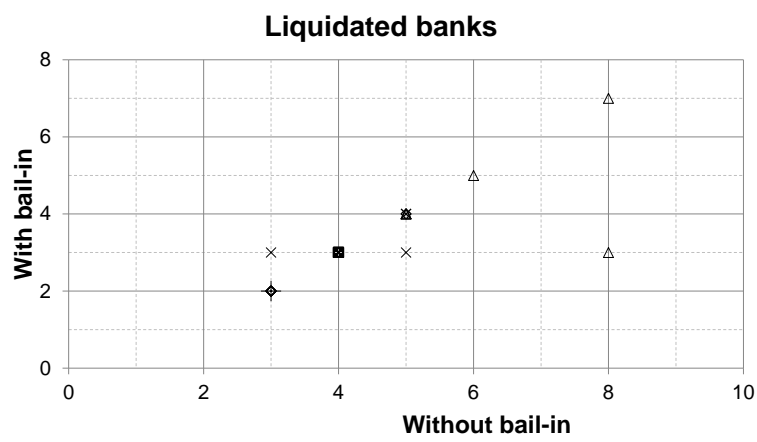

$\triangle \mathrm{S} 1 \square \mathrm{S} 2 \times \mathrm{S} 3 \diamond \mathrm{S} 4+$ No shock

(d)

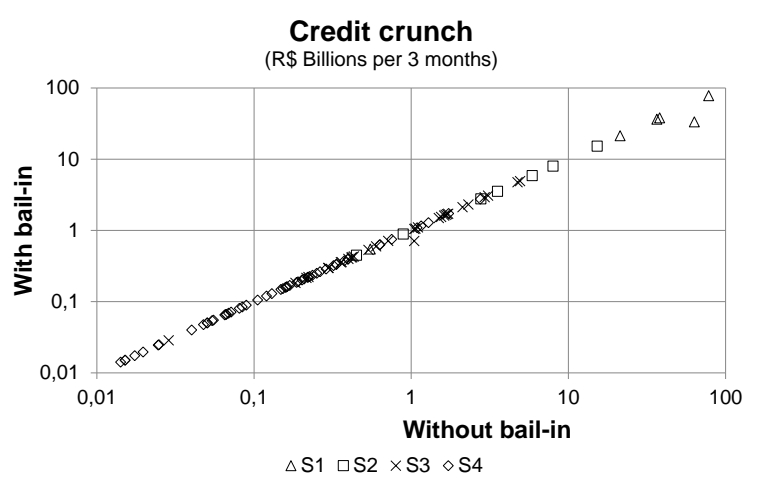

$(f)$

Figure 5: Comparison of outcomes of resolution processes with and without bail-ins, for simulations of large shocks on each single bank of the financial system in December 2016. Figure (a) compares the available bail-in resources to the minimum amount that the bank would need in case of a bail-in. Figure (b) compares the maximum losses that can be absorbed by each bank in order that it is not liquidated. Figures $(c)-(f)$ compare outcomes for resolution processes with and without bail-ins: $(c)$, contagion losses, $(d)$, the number of liquidated banks in the end of the processes, (e), the liquidation costs of liquidated banks, and $(f)$, the credit crunch. In Figures $(c),(e)$ and $(f)$, we plot the differences between the amounts computed for each shock scenario and a scenario without a shock.

will not make any payments to its creditors, imposing losses on them. If these creditors are resilient to these contagion losses, they are neither bailed in nor liquidated, otherwise there will be another round of contagion. Contagion losses when the bank is bailed in amount to the written-down debts, while in the case of liquidation, these losses are worth the full debt. However, these differences are hardly noticeable for two reasons. First, interbank exposures are comparatively small. Thus, in most cases, the default of a bank will not lead another bank into default. Second, most banks do not have enough resources for a successful bail-in. As such, if they need a bail-in, they will be liquidated anyway. Therefore, given the small quantity of available bail-inable resources that banks hold, the introduction 
of the bail-in in this type of extreme scenario will barely make any difference in the propagation of losses.

Figure 5(d) compares the number of liquidated banks after resolution processes with and without bail-ins. Again, the use of bail-inable resources to absorb losses would not prevent additional bank liquidations. However, there are two exceptions for scenarios targeting an S1 bank (also a D-SIB) and an S3 bank. In both cases, these banks experience successful bail-ins and thus would not be liquidated. These successful cases mitigate propagated losses. Had we not performed the bail-in, the prevented propagation of losses would be enough for breaking additional banks.

Figure 5(e) refers to the liquidation costs of liquidated banks. Since bail-ins do not recover most banks, except for the two mentioned before, the chart approximates a straight line ${ }^{34}$ Even in these two exceptions, liquidation costs of banks whose defaults are prevented by the bail-in are comparatively low. However, there is an outlier: it refers to a scenario in which the S4 bank that receives the shock also suffers contagion losses from a bank that is successfully bailed in in the scenario with no shock.

Figure 5(f) shows the impact on the real sector of including bail-in as a resolution process: the credit crunch arising from those liquidated banks that were unable to absorb the scenario shock. We proxy the credit crunch as the amount of credit that liquidated banks were granting in the last three months. Figure 5(f) reflects what is shown in Figure 5(d): liquidated banks in each scenario are the same for both resolution processes (except for the bank that is successfully bailed in in all scenarios). In these scenarios, the difference between the credit crunches computed for both processes is constant, except for the case of the scenario targeting the S1 bank already mentioned, in which there are three banks successfully bailed in.

Figures 6(a) and (b) display the effectiveness of including a bail-in into the resolution process. Figure 6(a) shows damage mitigation per unit of absorbed loss: the total contagion mitigation and the credit crunch mitigation per unit of loss absorption in the financial system. We compute the mitigated amounts using Equations (C.10) and (C.11). We include short-term losses from residual assets to be recovered in the long term because one of the purposes of a bail-in is to avoid turmoils related to frozen assets. Again, as the scenarios with and without bail-in are quite similar, the total contagion and credit crunch have almost identical reduction in each scenario (with the S1 bank scenario exception).

Finally, Figure 6(b) compares the systemic risk of the banking system just after the initial shock to the risk after the end of the resolution process when we consider bail-ins. Each point in the chart corresponds to the banking system's systemic risk measures $R_{D D R}$ computed using Equation (31) for each scenario. Here, we consider the economic value of bank $i, \varphi_{i}$ (Equations (B.6) and (31)), is given by the share of its total assets in the banking system. We consider the banking system's total assets after the resolution process are those of the non-liquidated banks in that state. We also take capital buffers from that state, without imposing any shock.

Figure 6(b) portrays, with three exceptions, that the systemic risk measures decrease mildly after the resolution process including a bail-in. This decrease is a combination of two opposing effects.

\footnotetext{
${ }^{34}$ In fact, there are small differences in some scenarios that happen when a contagion path hits the bank that is successfully bailed in, reducing its assets for recovery.
} 


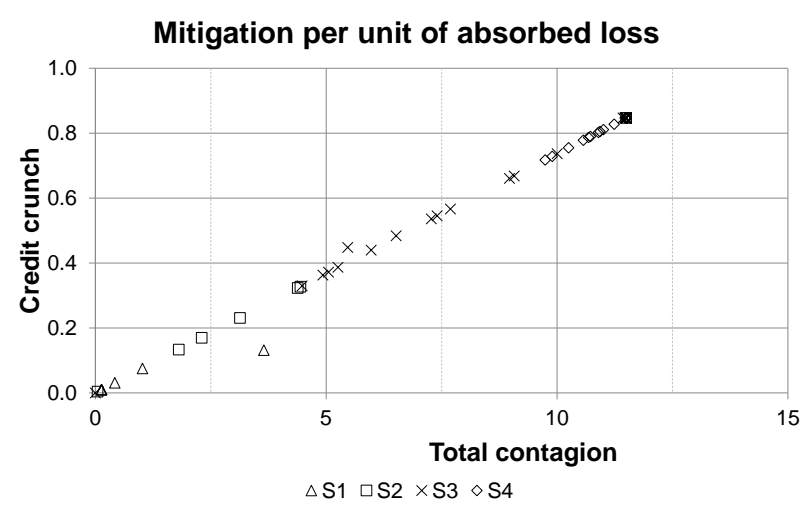

(a)

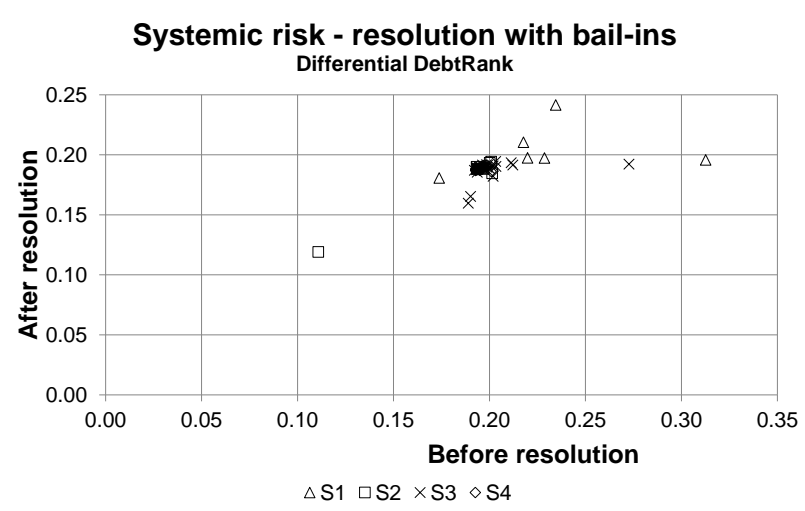

(b)

Figure 6: Measures for evaluating the effectiveness of using bail-inable resources during resolution. They are evaluated in simulations of large shocks imposed on each single bank of the financial system for December, 2016. Figure (a) shows contagion and credit crunch mitigation per unit of loss absorption, and (b), the comparison of Differential DebtRank measures before and after a resolution process that includes a bail-in.

Before the resolution process, the banking system is distressed by a large loss imposed on a single bank specified by the initial scenario. During the resolution processes, contagion may occur, distributing these losses across the system, weakening and stressing banks, thus increasing the systemic risk measure. On the other hand, the DebtRank-based risk measures do not include defaulted banks in the computation as their payments are frozen. This mechanically removes weaker banks from the system and decreases the systemic risk measure. The decrease that prevails in these simulations occurs because the mechanical removal of defaulted banks from the systemic risk evaluation has a stronger effect than the contagion losses that take place across the system.

To conclude, considering interbank exposures in uninsured/unsecured debt instruments are small (see Table 2), losses arising from simulations of large shocks targeting individual banks lead at most five additional banks into default for resolution processes without bail-ins. Only in two, from these 131 scenarios, ${ }^{35}$ bail-ins are effective in preventing the liquidation of additional banks. Given that only 13 banks have the possibility of being successfully bailed in, and that in just two extreme scenarios it is possible to successfully bail-in some of them, we conclude the available provision of bail-inable debt, especially for non-D-SIBs, is not sufficient to improve the loss-absorbing capacity of these banks in cases of contagion arising from large losses.

\subsection{Bail-ins: measuring the benefits to society}

The previous section showed the use of bail-inable resources during a resolution process is largely ineffective for scenarios of large losses to single banks. However, as losses experienced by banks are usually much smaller than these, we need to measure the benefits of successfully bailing in banks. Therefore, we simulate scenarios of losses for the 13 banks that are able to perform a successful bail-in. In these scenarios, we apply the maximum loss that each of these 13 banks could absorb and compare the outcomes between resolution processes with and without bail-ins.

\footnotetext{
${ }^{35}$ We consider the outcomes of shock scenarios after isolating them from those of the original state of the banking system. See explanation below Figure 5 (c) and its corresponding footnote.
} 
In Figure 7(a), we compare these bail-inable shocks with the corresponding banks' equities (right) for S1 banks (including all D-SIBs) and for other banks. We also compare these distributions of maximal bail-inable shocks/equities with distributions of negative ROEs in March 2009, computed for large and non-large banks. ${ }^{36}$ Large banks did not have negative ROEs in March 2009 while smaller banks generally did, despite these being of lower magnitude than the simulated shocks. This evidences shocks in our simulations are more severe than quarterly losses that banks experienced in Brazil during the financial crisis.

In Figure 7(b), we investigate the relationship between network topology and contagion measures. We use both (i) the large shocks defined in the previous section (identified by bank prudential segments) and (ii) the maximal bail-inable shock discussed in this section. In a successful bail-in, contagion losses occur only when there is write-down of liabilities. Only three banks have sufficient bail-inable debt to allow write-downs of liabilities during a bail-in. The others are able to use these resources only for recapitalization. Thus, only three banks generate contagion during a successful bail-in, of which only one is large enough to appear in the chart. The simulation of large shocks produces much larger contagion losses as these shocks are designed to wipe out all assets corresponding to uninsured and unsecured debt of the targeted bank, generating the greatest possible contagion. As we see, the normalized PageRank is roughly proportional to the contagion losses, except for some smaller banks (S3 and S4) with low PageRank values. These banks are in the periphery of the network and produce contagion losses ranging from zero to six billion Brazilian Reais, due to their interbank liabilities. In this figure, we also plot a linear regression between log values of both normalized PageRank and contagion losses. To rule out the effect from the smaller banks mentioned previously, we exclude data (57 banks) for which the normalized PageRank is below 0.032 .

We show the simulation results in Figure $(8)$. Figure 8 (a) shows the contagion losses of a resolution with bail-ins are much smaller than those from the process without bail-ins. The simulated bail-ins do not lead to any additional liquidation, as can be observed in Figure 8 (b) 37 , even in the cases of bailing in D-SIBs. Consequently, there were no additional costs or credit crunch after all the simulated bail-ins, as can be seen in Figures 8 (c) and (d).

Figure $8(e)$ shows damage mitigation per unit of absorbed loss computed according to Equations (C.10) and (C.11). For each simulation, we compute the total contagion losses and prevented credit crunch due to the bank's bail-in and compare them with the bank's bail-inable resources. Generally speaking, the amount of contagion losses mitigated, especially in the short term, when liquidated banks' assets are frozen, is larger than the amount of credit crunch.

Figure 8(f) shows a comparison between the Differential DebtRank measures that we calculate following the same lines discussed in the previous sections. We note that bailing in banks usually

\footnotetext{
${ }^{36}$ To compute these distributions, we select only negative ROEs from March 2009. These 46 negative ROEs are quarterly rates. We have chosen March 2009 as it is the quarter that presents the lowest total-assets-weighted ROE during the years around the financial crisis of 2008. We classify banks as large and non-large considering that at that time there were not formal definitions of prudential segments S1-S4. Large banks correspond to S1 banks.

${ }^{37}$ In this figure, the number of liquidated banks after a bail-in is always two, which is the number of liquidated banks in the process without a shock, i.e., is the number of banks of the database whose capital was already below the liquidation trigger in December 2016.
} 


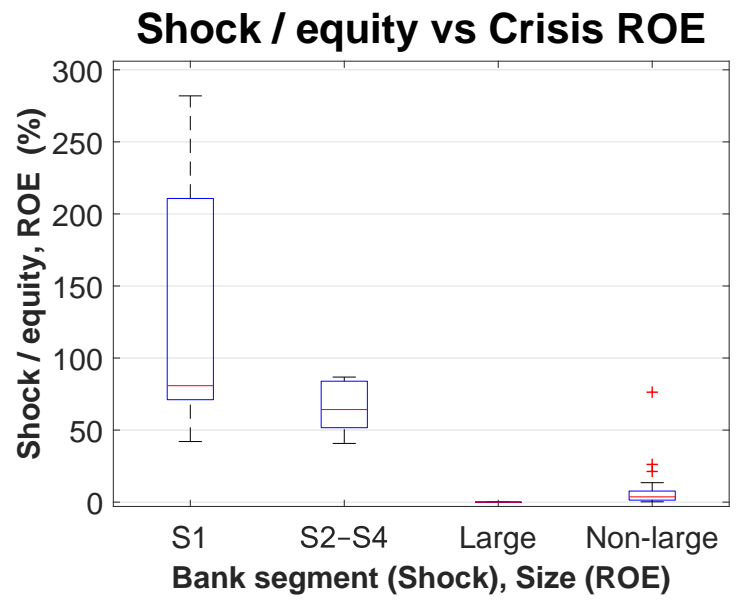

(a)

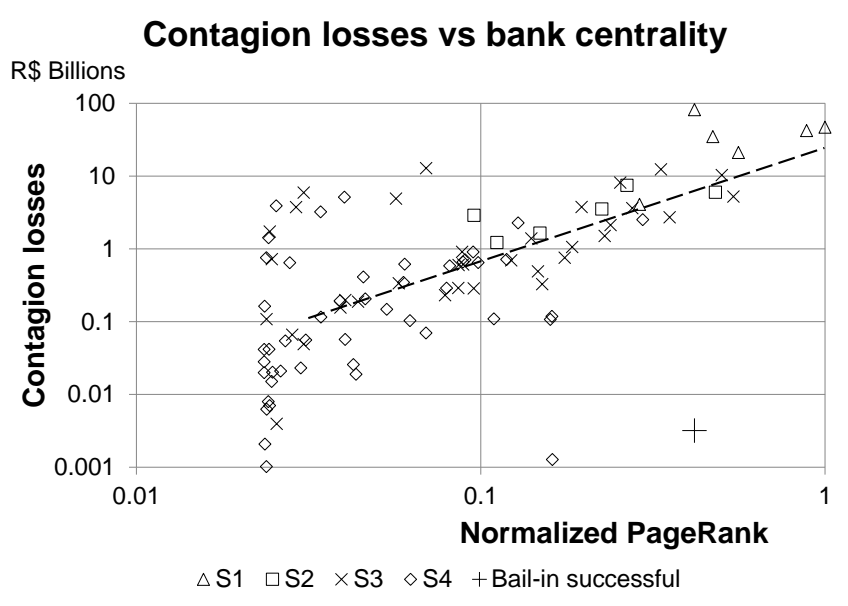

(b)

Figure 7: Simulation conditions regarding external shocks and network topology effects. Figure (a) shows distributions of the ratios of initial shocks applied to each bank and its corresponding equity. We segregate banks in segments S1 and S2-S4. We also compare these distributions with the negative quarterly ROEs experienced by large and non-large banks in Brazil. Figure (b), in turn, depicts the relationship between the PageRank centrality measure of the bank that receives the initial shock and the contagion losses after the end of the simulation.

reduces the systemic risk of the banking system. There is one exception related to an S2 bank with significant exposures to most of the largest banks ( $\mathrm{S} 1$ and $\mathrm{S} 2$ ). Bailing in this bank restores sound capital ratios. However, as the balance sheet downsizes, including its capital buffers, the bank becomes much more vulnerable to its exposures, which significantly raises the systemic risk measure after the bail-in.

\subsection{Bailing in D-SIBs: effects on the real sector}

In the previous section, we showed bail-ins are effective in preventing contagion of losses and credit crunch when they can be successfully applied. In this section, we focus on the potential benefits that bailing in D-SIBs may have on credit operations granted to the real economy, considering one of the main functions of the banking system is to provide financial intermediation through credit extension.

We analyze scenario outcomes in which we impose the largest loss that a D-SIB can suffer and still can be successfully bailed in, as in the previous section. Then, we compute the credit crunch that it would ensue if the bank had not been bailed in. We aggregate new credit operations data by economic sector of the borrower firm and the type of issued credit.

Table 7 summarizes our results broken down by economic sector and type of credit. The table shows the banking system's outstanding credit, the volume of new credit operations in the previous three months, the average credit crunch mitigated by bailing in a D-SIB and the ratio of the mitigated credit crunch to the credit operations in three months, which represents the average constraint in credit supply related to the liquidation of a D-SIB. Figure 9 shows the distributions of ratios of credit crunch mitigation to outstanding credit taken for each of the five D-SIBs by economic sector. In turn, Figure 10 shows these ratios by type of credit. 


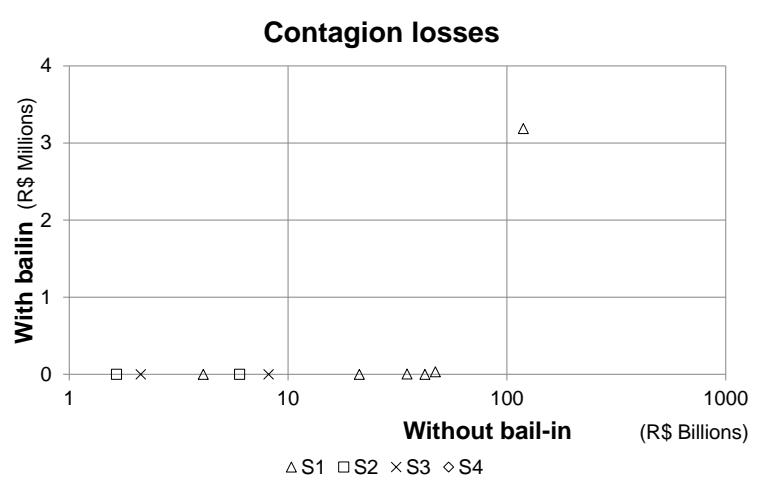

(a)

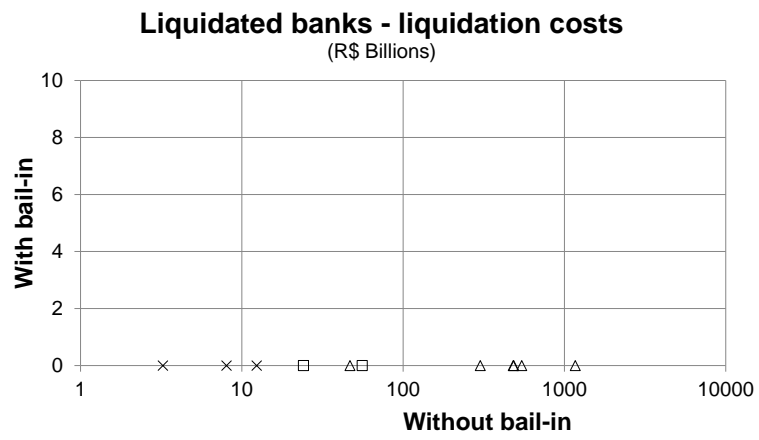

$\triangle \mathrm{S} 1 \square \mathrm{S} 2 \times \mathrm{S} 3 \diamond \mathrm{S} 4$

(c)

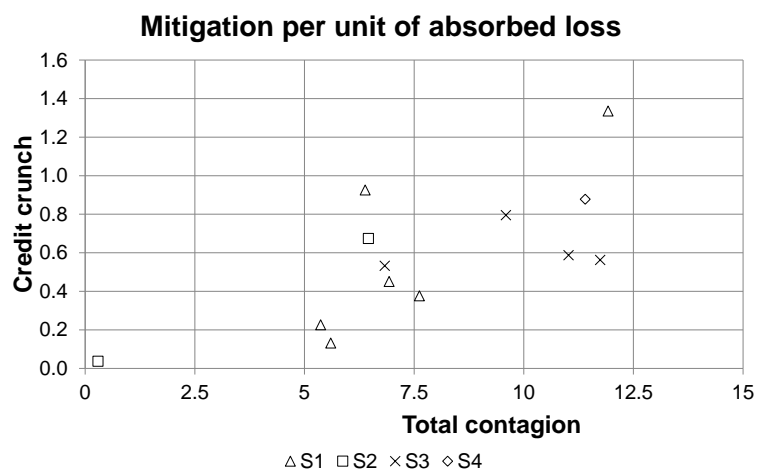

(e)

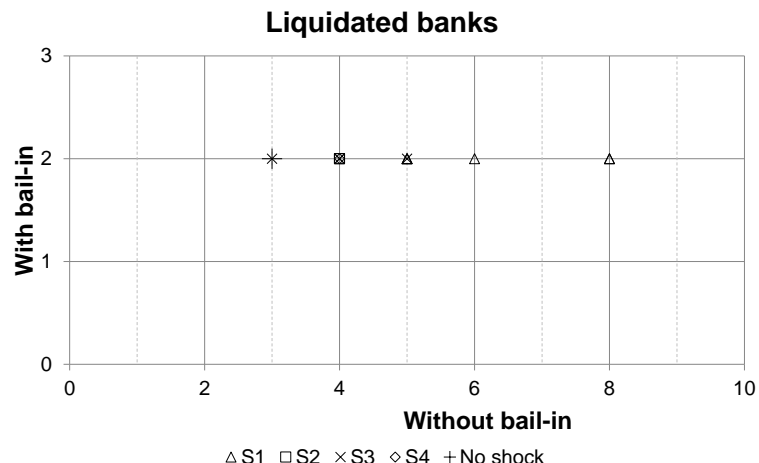

(b)

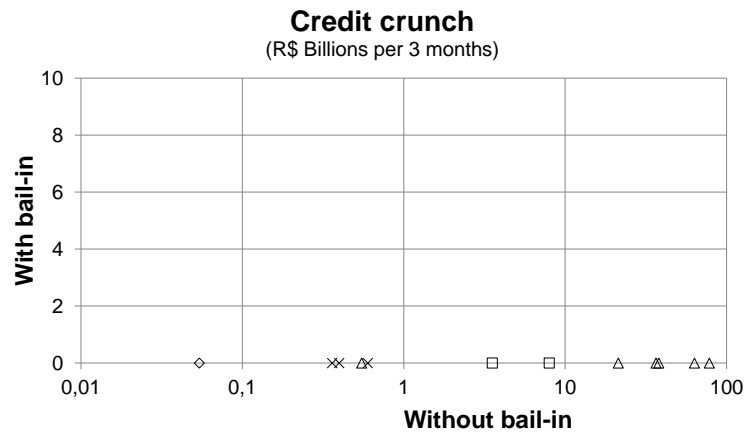

$\triangle \mathrm{S} 1 \square \mathrm{S} 2 \times \mathrm{S} 3 \diamond \mathrm{S} 4$

(d)

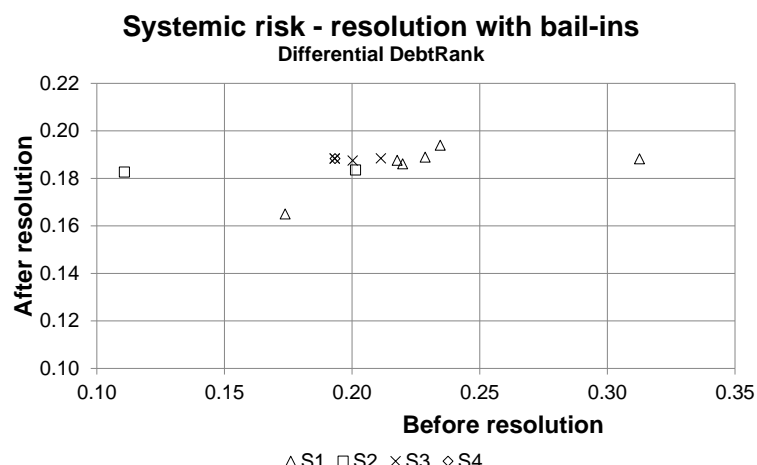

$(f)$

Figure 8: Comparison of outcomes of resolution processes with and without bail-ins, in which we simulate a shock on each bank in December 2016 that is equal to the maximum loss that it can be absorb by a bail-in. Figures (a) and (b) compare outcomes for resolution processes with and without bail-ins: (a), contagion losses, (b), the number of liquidated banks in the end of the processes, (c), the liquidation costs of liquidated banks, and $(d)$, the credit crunch at the end of the processes. Figure (e) shows total contagion and credit crunch mitigation per unit of loss absorption, and ( $f$ ), the comparison of Differential DebtRank measures for resolution processes with bail-ins, taken before and after the resolution processes. In Figure (a), we do not plot banks with no contagion losses. In Figures $(c)$ and $(d)$, we plot the differences between the amounts computed for each shock scenario and a scenario without a shock.

For most of the economic sectors, the average credit crunch mitigation achieved from bailing in a D-SIB is $16.52 \%$ of the new credit operations granted along the same period. This means that bailing in a D-SIB could prevent a significant reduction of external funding to the real sector, especially through loans and financing. This is particularly important for bank-oriented economies-such as Brazil-in which an average firm only relies on bank credit as a mean of external funding.

We can also compare this average reduction of credit supply with the distributions in Figures 9 and 10 . Figure 9 shows that, for most sectors, the largest mitigation to outstanding credit ratio is more 
Table 7: Simulation of the average impact of the bail-in of a D-SIB on credit to firms. Data from December, $2016(R \$ B n)$.

\begin{tabular}{lrrrr}
\hline & $(1)$ & $(2)$ & $(3)$ & $(4)$ \\
\hline Total & $4,484.05$ & 293.06 & 48.41 & 16.52 \\
& & & & \\
Economic sectors & & & & \\
E01 - Agriculture, forestry and fishing & 68.11 & 5.14 & 0.81 & 15.71 \\
E02 - Mining and quarrying & 96.25 & 3.26 & 0.53 & 16.23 \\
E03 - Manufacturing & $1,199.61$ & 98.81 & 16.90 & 17.11 \\
E04 - Electricity, gas, steam and air conditioning supply & 442.53 & 8.18 & 1.86 & 22.75 \\
E05 - Water supply; sewerage, waste management and re- & 53.31 & 1.01 & 0.18 & 18.34 \\
mediation activities & & & & \\
E06 - Construction & 296.76 & 11.06 & 1.97 & 17.85 \\
E07 - Wholesale and retail trade; repair of motor vehicles & 765.49 & 103.59 & 15.70 & 15.16 \\
and motorcycles & & & & \\
E08 - Transportation and storage & 428.30 & 11.66 & 1.92 & 16.46 \\
E09 - Accommodation and food service activities & 42.00 & 3.50 & 0.71 & 20.32 \\
E10 - Information and communication & 78.05 & 2.93 & 0.50 & 17.14 \\
E11 - Financial and insurance activities & 217.24 & 17.45 & 2.53 & 14.49 \\
E12 - Real estate activities & 69.37 & 2.02 & 0.25 & 12.42 \\
E13 - Professional, scientific and technical activities & 53.85 & 3.46 & 0.61 & 17.63 \\
E14 - Administrative and support service activities & 141.52 & 12.75 & 2.07 & 16.27 \\
E15 - Public administration and defense; compulsory social & 377.23 & 1.36 & 0.27 & 19.84 \\
security & & & & \\
E16 - Human health and social work activities & 43.88 & 3.43 & 0.91 & 26.62 \\
E17 - Other & 110.56 & 3.45 & 0.67 & 19.34 \\
& & & & \\
Type of credit & & & & \\
Loans & $1,197.93$ & 102.47 & 19.11 & 18.65 \\
Financing & $3,061.74$ & 114.14 & 18.26 & 16.00 \\
Leasing & 36.77 & 2.98 & 0.86 & 28.71 \\
Other & 187.61 & 73.47 & 10.18 & 13.86 \\
\hline
\end{tabular}

This table displays data on credit granted by banks to firms aggregated for the whole economy, for economic sector and for type of credit. Column (1) shows the outstanding credit granted by the banking system, (2), the banking system's new credit in the last 3 months, (3) the average credit crunch mitigation computed for scenarios that simulate the bail-in of each D-SIB, and (4) is the ratio $(3) /(2)$, in $\%$.

than twice that of the median of the distribution. This means there are D-SIBs whose failure would cause a credit crunch of about $25 \%$ to $30 \%$ in the short term in some economic sectors, generating an increase in the demand for credit that would not be easily met by other banks due to capital requirements' constraints. The comparison of columns (1) and (2) from Table 7 shows the ratio of new credit to outstanding credit is around $6 \%$ for most economic sectors, while for the trade sector (E07), the ratio is about $14 \%$, meaning this sector depends more on short-term operations and could be more affected by a potential credit crunch.

In Figure 10, the ratios of mitigation to outstanding credit reach almost $10 \%$ for the type of credit "Other." However, this does not correspond to large monetary amounts of mitigation as the corresponding outstanding credit is about $4 \%$ of the total outstanding credit. Regarding the type of credit "Loans," 
there is a D-SIB that is an outlier, not shown in the chart, whose failure would produce a credit crunch of about $30 \%$ in the short term. In turn, the market of leasing operations, although representing less than $1 \%$ of outstanding credit, has two D-SIBs whose failure would produce a remarkable credit crunch for this type of credit. However, this credit crunch could be absorbed by other banks, at least from the point-of-view of capital requirements, as the involved amounts are comparatively very small.

To summarize, this section highlights the systemic importance of D-SIBs for the real economy and the role that a bail-in can play to effectively prevent disruptions in financial intermediation. Our results show the type of credit that is most sensitive to a D-SIB failure is loans. The D-SIB that would produce the largest credit crunch in loans is the same that would produce the largest credit crunch for 13 out of the 17 economic sectors, which highlights its relevant role in credit activity. An economic sector whose vulnerability to credit crunches should be monitored is trade, due to its size and greater share of new credit operations in three months.

\section{D-SIBs - Credit crunch mitigation}

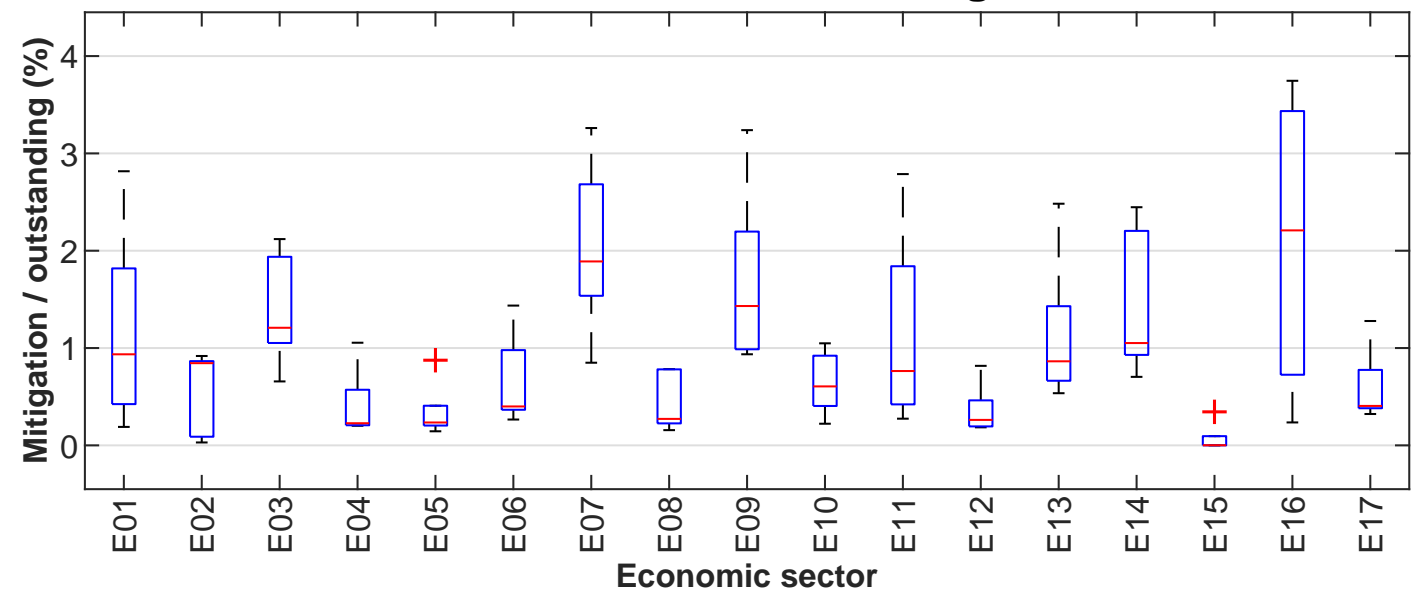

Figure 9: Distributions of the banking system's credit crunch mitigation computed for simulations of resolution processes in which a D-SIB receives a shock and is successfully bailed in. The box plot shows the distributions of ratios of credit crunch mitigated to the outstanding credit to firms for each economic sector defined according to Table 7 We perform these simulations for December, 2016.

\subsection{Requirements of bail-inable resources}

In this section, we use our methodology to provide a toolbox for helping Resolution Authorities in evaluating costs and benefits of introducing requirements of bail-inable instruments. A hypothetical introduction of these requirements would increase the likelihood of a successful bail-in, in the case it is necessary. First, we analyze the effects of different and hypothetical bail-in requirement levels on the number of banks that could be successfully bailed in. Second, we compare the total losses incurred by a single D-SIB if it is bailed in against those when it is not, for shocks of different magnitudes. We perform this comparison by considering the bank's actual levels of bail-inable resources. Finally, we compute the amount of bail-inable resources required for absorbing shocks of different magnitudes in a bail-in for the same bank.

Initially, we build counterfactual scenarios of requirements for bail-inable instruments and study 


\section{D-SIBs - Credit crunch mitigation}

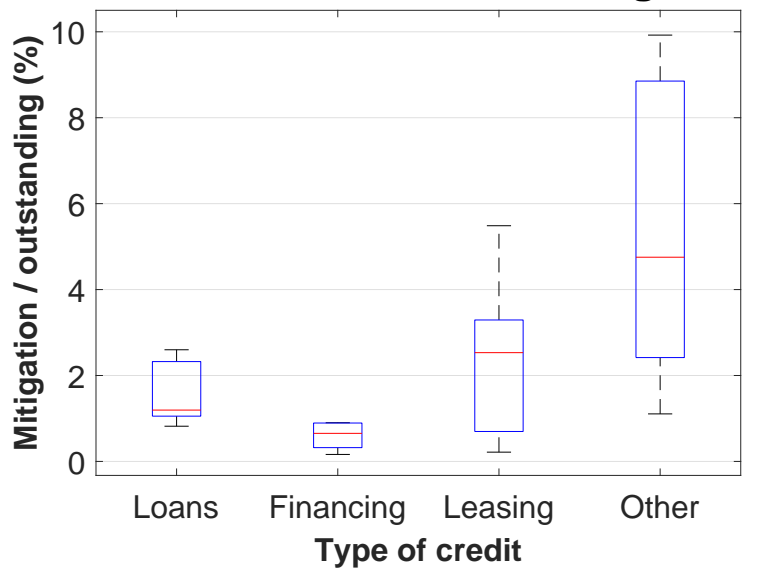

Figure 10: Distributions of the banking system's credit crunch mitigation computed for simulations of resolution processes in which a D-SIB receives a shock and is successfully bailed in. The box plot shows the distributions of ratios of credit crunch mitigated to the outstanding credit to firms for each type of credit granted defined according to Table 7 We perform these simulations for December, 2016.

how they would affect the likelihood of a successful bail-in for different bank segments. We perform this exercise for two levels of needed bail-inable resources: (a) with minimum recapitalization bail-in and (b) with full recapitalization bail-in. In both, bail-inable resources are employed only for recapitalization. In the minimum recapitalization bail-in, bail-inable resources are used for recapitalizing the bank from the capital level below which a bail-in is triggered. In the full recapitalization bail-in, these resources are employed for recapitalizing the bank from a zero capital level. In both cases, the target capitalization level is the average of capital ratios of the peer group.

For this study, we also define the requirement ratio as the ratio of bail-inable resources of the bank to its potential maximum, which is the sum of its subordinated/convertible debt to its total senior uninsured unsecured debt. We define this amount regardless of the bank's prudential segment. Additionally, we compute the resources required for a minimum recapitalization bail-in using Equation (C.3), as already done in Figure 5(a), and the resources needed by a full recapitalization bail-in from Equation (C.4). Finally, we compute the number of banks from each segment that have enough bail-inable resources at each requirement ratio and show the results in Figures 11(a) and 11.(b). In these computations, we consider, for a given requirement ratio, banks have at least their current level of bail-inable resources 38 .

We observe that all S1 banks would have enough resources for a minimum recapitalization bailin, but only two of them could be fully recapitalized. The full recapitalization bail-in of the six S1 banks would need a requirement ratio of 0.41 or more. Concerning S2 banks, only two would be bail-inable. To successfully bail-in all of them, the requirement ratio should be 0.23 or more. For their full recapitalization bail-in, the requirement ratio should be 0.48. Conversely, some S3 and S4 banks could not be bailed in even under a requirement ratio of 1.00. Generally speaking, a requirement ratio of about 0.15 would enable a minimum recapitalization bail-in of all S1, six (out of seven) S2, and more than the half of the S3 banks. As a policy recommendation, it is desirable to bail-in banks

\footnotetext{
${ }^{38}$ If the requirement of bail-inable resources of the bank is less than its current level of bail-inable resources, we use its current level of bail-inable resources in the simulations.
} 
as soon as their capital indices reach the triggering level of the bail-in. Otherwise, the needs of bailinable resources can quickly become high even if compared with the amount of all potential bail-inable instruments.

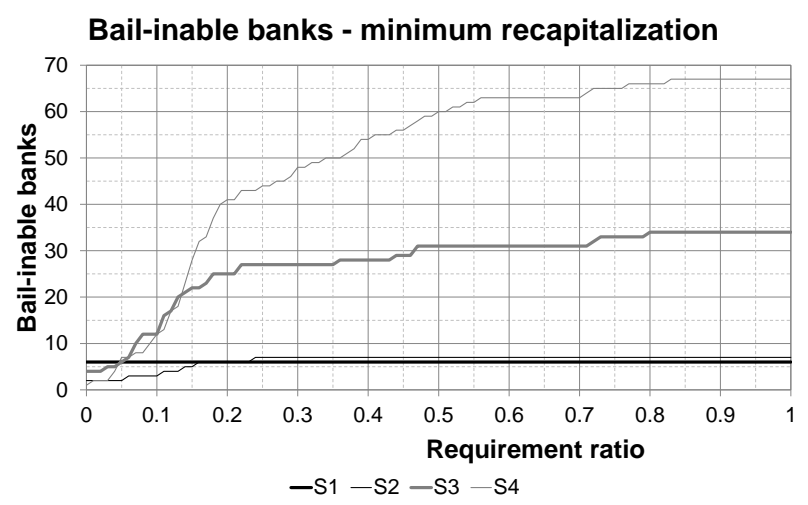

(a)

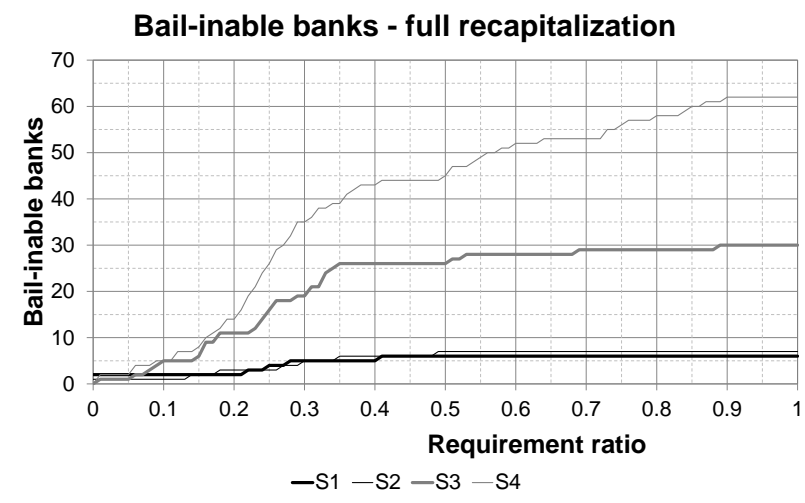

(b)

Figure 11: Number of banks of each prudential segment that can be bailed in under a given bail-inable resources requirement ratio. These numbers of banks are computed for (a) bail-in starting when banks lose compliance with capital requirements, and (b), bail-in starting when banks lose all their capital buffer.

Next, we study the effects of different shock magnitudes and the consumption of bail-inable resources to absorb these shocks in a bail-in. We perform this study for a single D-SIB, as the consequences of letting it break or bailing in it may be relevant for the financial system. In Figure 12 (a) we compare the total losses, for resolution with and without a bail-in, that result from an initial shock for different shock levels. Shock and losses are plotted as a ratio to the bank's total assets. For reference, we depict along the $\mathrm{x}$-axis the events related to the shock sizes as they increase. In a first moment, shocks are absorbed by the capital buffer (CB) until they reach the bail-in triggering level (B). If shocks are greater than that and the bank is not bailed in, it will be liquidated. The bail-in resources can absorb larger losses until the shock reaches the maximum bail-inable shock (M). For shocks greater than that, bail-inable resources are not sufficient and the bank will be liquidated. (M) is less than the capital buffer, which means that this bank cannot withstand a full recapitalization bail-in. Shock levels (SD) and (M) are greater enough to extinguish, respectively, all of its subordinated/convertible debt and all of its total senior uninsured unsecured debt. Regarding losses, as far the bank is not liquidated, they equal those imposed by the shock. After liquidation, we use the short-term approach that considers the freeze of the remainder of the uninsured unsecured assets, that is, in the short term, creditors only recover their insured or secured debt regardless of the level of the shock that led the bank to a breakdown.

In Figure 12(b), we compare, for the same bank, the use of bail-inable resources required for absorbing increasing levels of shock. We compute the written-down resources and the bail-inable resources used in recapitalization using Equations $(\overline{C .5})$ and $(\overline{C .7})$. We also depict along the $x$-axis the same loss magnitudes as in the previous figure. Shock and resources required are plotted as ratios to the maximum bail-inable resources. The figure shows that from a zero shock level to the shock for which a bail-in should be triggered, the use of bail-inable resources is zero. For shocks greater than this to shocks that wipe-out the capital buffer, only recapitalization to the target capital indices levels 
is performed. For shocks above the capital buffer, there is write-down of debts, that is, creditors incur in permanent losses, instead of having their debt assets converted into capital. Points SD and T in the $y$-axis allow the visualization of the magnitude of shocks for which a bail-in would consume the whole stock of subordinated/convertible debt and of the senior uninsured unsecured debt, respectively. From this figure we see that if this bank's bail-inable resources were only its subordinated/convertible debt, these resources would be barely enough for its full recapitalization.

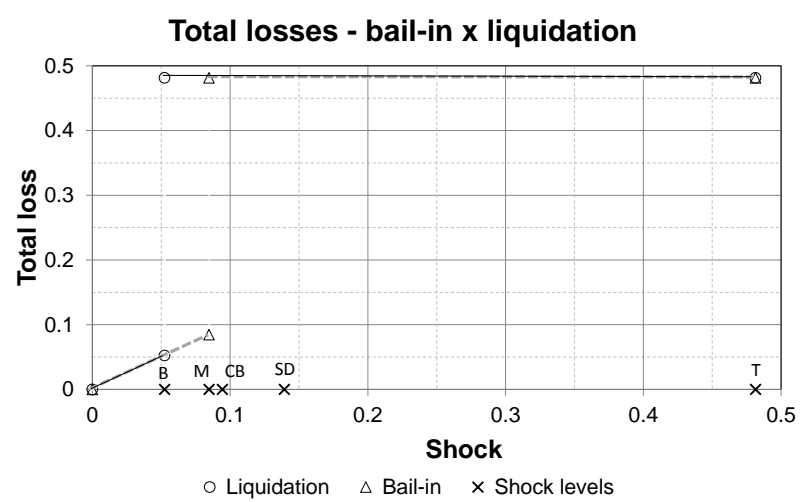

(a)

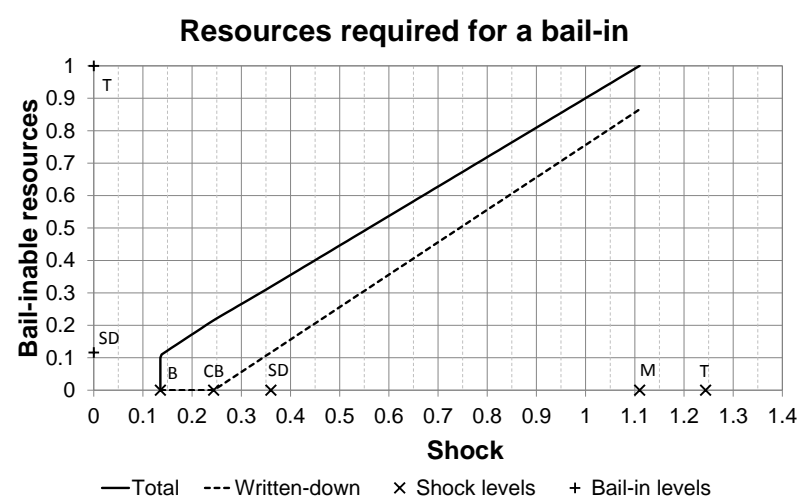

(b)

Figure 12: Analyses of requirements of bail-inable resources for a particular D-SIB. Figure (a) displays a comparison of total losses suffered by the bank after a given shock, considering its current bail-inable resources. Total losses and shocks are plotted as a ratio to the bank's total assets. Figure (b) shows the amounts of resources required for bailing in the bank for a given shock. In this figure, bail-inable resources and shock are plotted as a ratio to the maximum debt that could be allocated by a bail-in requirement. In both figures, $B$ is a shock that triggers a bail-in, $M$ is the maximum bail-inable shock, $C B$ is the capital buffer, $S D$ is the one that requires the write-off of the subordinated/convertible debt and $T$ is the shock that also extinguishes the entirety of the senior uninsured unsecured debt.

\section{Conclusion}

This paper investigates the benefits to the banking system and to society of a potential introduction of bail-ins as a bank resolution tool. We analyze the efficiency of bail-ins in the economy, both in the financial and real sectors. Efficiency is measured by comparing models with the adoption of bailins against the traditional bank liquidation procedure in the short term. In the financial sector, we look at efficiency as the loss reduction bail-ins would provide to the system in the case banks experience a negative event. In the real sector, we look at potential credit crunches that bail-ins would prevent when a bank is successfully bail-ined instead of being liquidated. Our model considers the way banks are interconnected and provides quantitative insights of which sectors in the real economy or types of banks would benefit the most from the introduction of the bail-in as a bank resolution scheme.

We explore a rich and unique dataset provided by the $\mathrm{BCB}$ to perform a case study for our methodology. Using data from December 2016, we find the Brazilian interbank exposures are comparatively small. Thus, in most cases, the default of a bank will not lead another bank into default. Additionally, the allocation of bail-inable instruments within the Brazilian banking system is such that losses originated from bail-ins mostly induce small contagion risk among banks as bail-inable debt is mostly held by non-banks. Even when banks are exposed to bail-inable instruments, they are of higher seniority and therefore are the last to absorb losses in the hierarchy when needed. 
The bail-in effectiveness in Brazil would be limited to the larger banks because most S2 to S4 banks do not have enough resources for a successful bail-in. The simulations show that only $9 \%$ of the banks would have the required bail-inable resources to be successfully bailed in. Therefore, in most of these cases, the credit crunch and the amount of frozen assets would not significantly change with the adoption of bail-ins.

Considering that the introduction of bail-in is a core strategy to deal with moral hazard while preserving the continuity of the critical functions of the banking system, we perform a series of simulations in which banks suffer the maximum loss that can be handled through a bail-in. In these simulations, we can observe the benefits of bail-ins for the larger banks, the additional loss-absorbing capacity brought by their bail-in reaches tens of $\mathrm{R} \$$ billions. Using this extra capacity reduces credit crunch and liquidation costs to zero. This cost-benefit relationship allows us to define a measure of the effectiveness of a bail-in process by computing the harm prevented by unit of bail-inable debt employed in loss absorption. The mitigation of total contagion per unit of absorbed loss for most simulations is above five, i.e., each unit of bail-inable debt consumed prevented the freeze of at least five units of debt.

We also analyze the effects on the real sector in terms of credit crunch avoided by bailing in Brazilian D-SIBs. The analyses show the type of credit most sensitive to the failure of a D-SIB is loans. There is a D-SIB that produces a remarkably larger credit crunch than other D-SIBs. Regarding credit crunch to economic sectors, there is a similar concentration of credit crunches with respect to D-SIBs. An economic sector whose vulnerability to credit crunches is relevant is trade, due to its size and greater share of short-term credit operations.

Finally, we present a toolbox for supporting resolution authorities. We study the consequences of implementing hypothetical requirements of bail-inable instruments for the Brazilian banking system. We find requirements of the order of $15 \%$ of the potentially bail-inable debt would substantially improve the success of the bailing in of S2 and S3 banks.

For future research, we suggest including liquidity and information contagion effects in the model, which would improve the assessment of causes and effects of possible bank runs and thus provide better support to decision-making related to bank resolution.

\section{References}

Bardoscia, M., Battiston, S., Caccioli, F., and Caldarelli, G. (2015). Debtrank: a microscopic foundation for shock propagation. PLoS ONE, 10(6):e0130406.

Battiston, S., Puliga, M., Kaushik, R., Tasca, P., and Caldarelli, G. (2012). Debtrank: Too central to fail? Financial networks, the FED and systemic risk. Scientific Reports, 2(541).

Beck, T., Da-Rocha-Lopes, S., and Silva, A. (2017). Sharing the pain? Credit supply and real effects of bank bail-ins. Centre for Banking Research Working Paper Series - WP 01/17, Cass Business School. 
Cechetti, S. and Schoenholtz, K. (2017). Bank resolution: The importance of a public backstop. VoxEU, 28 May.

Conlon, T. and Cotter, J. (2014). Anatomy of a bail-in. Journal of Financial Stability, 15:257-263.

Eisenberg, L. and Noe, T. H. (2001). Systemic risk in financial systems. Management Science, 47(2):236-249.

Fricke, D. and Lux, T. (2015). Core-periphery structure in the overnight money market: Evidence from the e-MID trading platform. Computational Economics, 45(3):359-395.

FSB (2014). Key attributes of effective resolution regimes for financial institutions. Available at http://www.fsb.org/wp-content/uploads/r_141015.pdf

Hüser, A.-C., Hałaj, G., Kok, C., Perales, C., and van der Kraaij, A. (2018). The systemic implications of bail-in: A multi-layered network approach. Journal of Financial Stability, 38:81 - 97.

in't Veld, D. and van Lelyveld, I. (2014). Finding the core: Network structure in interbank markets. Journal of Banking and Finance, 49:27-40.

Jansen, D.-J., Mosch, R., and van der Cruijsen, C. (2013). When does the general public lose trust in banks? DNB Working Papers 402, De Nederlandsche Bank.

Klimek, P., Poledna, S., Farmer, J. D., and Thurner, S. (2015). To bail-out or to bail-in? Answers from an agent-based model. Journal of Economic Dynamics and Control, 50:144-154.

Laeven, L. and Valencia, F. (2012). Systemic banking crises database: an update. IMF Working Paper WP/12/163, IMF.

Lehmann, M. (2017). Bail-in and private international law: how to make bank resolution measures effective across borders. International and Comparative Law Quarterly, 66(1):107-142.

Martinez-Jaramillo, S., Alexandrova-Kabadjova, B., Bravo-Benitez, B., and Solórzano-Margain, J. P. (2014). An empirical study of the Mexican banking system's network and its implications for systemic risk. Journal of Economic Dynamics and Control, 40:242-265.

Martynova, N. and Perotti, E. (2018). Convertible bonds and bank risk-taking. Journal of Financial Intermediation, 35:61 - 80.

Philippon, T. and Salord, A. (2017). Bail-ins and bank resolution in Europe: A progress report. Geneva Reports on the World Economy Special Report 4, CEPR.

Poledna, S., Molina-Borboa, J. L., Martínez-Jaramillo, S., van der Leij, M., and Thurner, S. (2015). The multi-layer network nature of systemic risk and its implications for the costs of financial crises. Journal of Financial Stability, 20:70-81.

Schoenmaker, D. (2017). A macro approach to international bank resolution. Available at https: //ssrn. com/abstract=2997220. 
Silva, T. C., Silva, M. A., and Tabak, B. M. (2017a). Systemic risk in financial systems: a feedback approach. Journal of Economic Behavior and Organization, 144:97-120.

Silva, T. C., Souza, S. R. S., and Tabak, B. M. (2016). Network structure analysis of the Brazilian interbank market. Emerging Markets Review, 26:130-152.

Silva, T. C., Souza, S. R. S., and Tabak, B. M. (2017b). Monitoring vulnerability and impact diffusion in financial networks. Journal of Economic Dynamics and Control, 76:109-135.

Souza, S. R. S. (2016). Capital requirements, liquidity and financial stability: The case of Brazil. Journal of Financial Stability, 25:179-192.

Souza, S. R. S., Silva, T. C., Tabak, B. M., and Guerra, S. M. (2016). Evaluating systemic risk using bank default probabilities in financial networks. Journal of Economic Dynamics and Control, 66:5475.

Tröger, T. H. (2018). Too complex to work: A critical assessment of the bail-in tool under the european bank recovery and resolution regime. Journal of Financial Regulation, 4(1):35-72.

\section{Appendix A Example: evolution of a bail-in process}

In this section, we provide an example of the application of the bail-in process defined in Section 4.1 under different shock scenarios. Suppose the bank has the following balance sheet composition: total assets 100, liabilities 90, shareholders' equity 10, and, for simplicity, consider the capitalization is computed as the ratio of the shareholders' equity to total assets. Additionally, suppose the amount of subordinated/convertible debt is 15 , the senior uninsured/ unsecured debt of qualified holders worths 20 and the bank is a D-SIB, which means the stock of non-bail-inable debt worths 55 . The capitalization level that starts a bail-in is $4.5 \%$ and the target capitalization level is $10 \%$. Consider the following scenarios:

a) Initial loss is 5. In this case, total assets will be 95 after the shock. The adjustment required affects only the shareholders' equity, which will absorb the whole loss. After this, it will be worth 5. In this case, as the capitalization after the initial loss is 5\%, the bank does not undergo a bail-in.

b) Initial loss is 8 . In this case, there will be a bail-in as the bank's capitalization falls down to $2 \%$. Shareholders' equity absorbs the loss completely, being worth 2 afterwards, thus it will not be necessary to write-down any bail-inable debt. However, these resources will take part in the recapitalization process needed to provide a shareholders' equity level of $10 \%$ of the total assets (92). To this end, it will be necessary to convert 7.2 units of subordinated/convertible debt into capital. The bail-in process ends with total assets equal to 92, shareholders' equity 9.2, liabilities 82.8 , subordinated/convertible debt 7.8 and the other items unchanged.

c) Initial loss is 20 . In this case, there will be a bail-in given that the bank's capitalization becomes negative. Shareholders' equity absorbs part of the loss and gets depleted. There remains a loss of 
10 units to be absorbed through write-downs. The first seniority class of debt to absorb this loss is the subordinated/convertible debt. It absorbs completely the loss through a write-down of 10. After the write-down, it is necessary to recapitalize the bank to the level of $10 \%$ of the total assets (80). Thus, it is necessary to convert 8 units of bail-inable debt into capital. Considering there are only 5 units of subordinated/convertible debt after the write-down, we use the next seniority class of bail-inable debt. If the bank was not a D-SIB, these debt instruments would not be bail-inable and the bank would have to be liquidated, with residual assets of 80 . However, the bank is a DSIB, then, we convert 3 units of senior uninsured unsecured debt into capital. The bail-in process ends as follows: total assets 80 , shareholders' equity 8 , liabilities 72 , subordinated/convertible debt 0 , senior uninsured unsecured debt 17, non bail-inable debt 55 .

\section{Appendix B Systemic risk measurement}

Our measure of the systemic risk of the banking network is based on the Differential DebtRank measure proposed in Bardoscia et al. (2015). We use it to measure the systemic risk just after imposing an initial loss (shock) to the banking system and after the resolution process has ended. During the resolution process, the liquidated banks are removed from the network. As explained previously, the interbank claims towards these banks are considered to be zero in the short term. Thus, the exit of these banks from the network has two opposite effects: on the one hand, their creditors are weakened, on the other hand, the exit of a fragile bank contributes to strengthen the whole system.

\section{B.1 DebtRank}

The original DebtRank is a stress level measure that considers a mechanism of impact propagation over a vulnerability network that represents the financial system under study. In this paper, the process takes place over the vulnerability network of the interbank market $\boldsymbol{V} \in \mathscr{B} \times \mathscr{B}$, in which $\mathscr{B}$ is the set of banks. This matrix is used as the basis for the computation of the stress levels of each of the participant banks and is defined as:

$$
\boldsymbol{V}=\left[v_{i j}\right]_{\forall i, j \in \mathscr{B}}, \quad \boldsymbol{A}=\left[a_{i j}\right]_{\forall i, j \in \mathscr{B}}, \quad v_{i j}=\frac{a_{i j}}{E_{i}}
$$

with $v_{i j} \in[0, \infty)$. The entry $a_{i j}$ represents the exposure of bank $i$ towards $j$ in the interbank network and $E_{i}$ is the capital buffer of bank $i$. Case $v_{i j} \geq 1$, the default of bank $j$ leads $i$ into default as well. For values within the interval $(0,1)$, the default of $j$ leads $i$ into distress but not into default.

DebtRank computes the additional stress caused by some initial shock using a dynamic system, with two variables for each bank $i \in \mathscr{B}$ :

- $h_{i}(t) \in[0,1]$ is the stress level of $i$. When $h_{i}(t)=0, i$ is undistressed; if $h_{i}(t)=1, i$ is on default, and intermediate values represent the partial stress of $i$. 
- $s_{i}(t) \in\{U, D, I\}$ is a categorical variable and represents the state of $i$. $U, D$, and $I$ stand for undistressed, distressed, and inactive, respectively.

The dynamic system evolves according to the following rules:

$$
\begin{aligned}
& h_{i}(t)=\min \left(1, h_{i}(t-1)+\sum_{j \in \mathscr{D}(t)} v_{i j} h_{j}(t-1)\right), \\
& s_{i}(t)= \begin{cases}D, & \text { if } h_{i}(t)>0 \text { and } s_{i}(t-1) \neq I, \\
I, & \text { if } s_{i}(t-1)=D, \\
s_{i}(t-1), & \text { otherwise. }\end{cases}
\end{aligned}
$$

in which $t \geq 0$ and $\mathscr{D}(t)=\left\{u \in \mathscr{B} \mid s_{u}(t-1)=D\right\}$. The summation in (B.2) occurs over the banks that got distressed in the previous iteration. Once distressed, they become inactive in the next iteration due to $(\mathrm{B} .3)$, becoming unable to propagate further stress (see Battiston et al., 2012 for more detail.)

We denote as $T$ the number of steps in which the system converges. We compute the resulting DebtRank due to the initial stress vector $\boldsymbol{h}(0)$ as:

$$
D R(\boldsymbol{h}(0))=\sum_{i \in \mathscr{B}}\left(h_{i}(T)-h_{i}(0)\right) \varphi_{i}
$$

in which $\varphi_{i}$ denotes the economic value of $i$. Observe that we subtract the initial stress vector $\boldsymbol{h}(0)$ from the DebtRank computation. Hence, it conveys the notion of additional stress given an initial shock scenario.

The great shortcoming of this formulation is banks do not propagate second- and high-order rounds of stress. Thus, once a bank propagates stress, it will never be able to propagate additional stress due to subsequent impacts that it receives. This can lead to severe underestimation of the stress levels of banks. The Differential DebtRank, described in next section, overcomes this shortcoming, thus, it will be used in this paper as the measure for gauging the banking system's systemic risk.

\section{B.2 Differential DebtRank}

By introducing states for the inactivation of banks that have performed a first propagation, Battiston et al. (2012) intend to prevent stress double-counting due to second- or high-order impacts through different network vulnerability routes or cycles. Additionally, in such cases, the lagged stress level in (B.2) serves as an amplifying feedback mechanism, as stress levels are non-decreasing over time.

It is possible to overcome these shortcomings by using stress differentials between one iteration and another. As a result, at each iteration, banks are only allowed to propagate the stress increment that 
they receive from the previous iteration. If a bank defaults at time $t$, it no longer propagates financial stress during the dynamic process after $t$.

Bardoscia et al. (2015) incorporate that idea of propagating stress differentials and not stress levels by modifying (B.2) as follows:

$$
\begin{aligned}
h_{i}(t) & =\min \left(1, h_{i}(t-1)+\sum_{j \in \mathscr{B}} v_{i j}\left[h_{j}(t-1)-h_{j}(t-2)\right]\right) \\
& =\min \left(1, h_{i}(t-1)+\sum_{j \in \mathscr{B}} v_{i j} \Delta h_{j}(t-1)\right),
\end{aligned}
$$

in which $t \geq 0, h_{i}(0)$ is the exogenous initial stress scenario, $h_{i}(t)=0, \forall t<0$, and $\Delta h_{j}(t-1)=$ $h_{j}(t-1)-h_{j}(t-2)$ is the stress differential of the bank $j$ at the previous iteration $t-1$. We can then compute the Differential DebtRank value related to an initial stress vector $\boldsymbol{h}(0)$ using $(\mathrm{B} .4)$ with the converged stress values of $(B .5)$ :

$$
\operatorname{DDR}(\boldsymbol{h}(0))=\sum_{i \in \mathscr{B}}\left(h_{i}(T)-h_{i}(0)\right) \varphi_{i}
$$

Concerning the vulnerability matrix, Bardoscia et al. (2015) propose that it is time-dependent, that is, $\boldsymbol{V}(t)$. Specifically, they update $\boldsymbol{V}(t)$ by setting to zero the columns corresponding to those banks that default at time $t$. In this paper, we consider this matrix as fixed over time because the differentials of banks $j \in \mathscr{B}$ that default at time $t$ are $\Delta h_{j}(t+k)=0, \forall k>0$. Once defaulted, they are sterilized in the dynamic process and no longer propagate stress.

In fact, the original DebtRank represents the lower bound for the differential DebtRank. In the case of no multiple vulnerability routes or cycles, the differential DebtRank produces the same results as the original DebtRank.

\section{Appendix C Definition of diagnostic variables}

This appendix defines the variables we use to evaluate the initial and final conditions of the banking system related to a resolution process.

Bail-in assessment variables: We first present variables that assess the possibility of bailing in a bank and the associated outcomes of the process. These variables use as input the bank $i$ 's variables before any loss imposed by the simulations' scenarios. They also consider that losses affect the bank's $R W A$ besides affecting assets and capitalization variables. Below, we define each of these variables.

a) Available bail-inable resources: $D_{i}^{B}$ quantifies bank $i$ 's bail-inable debt as follows: 


$$
D_{i}^{B}= \begin{cases}D_{i}^{1}+D_{i}^{2} & \text { if } i \text { is a D-SIB } \\ D_{i}^{1} & \text { otherwise }\end{cases}
$$

b) Maximum absorbable loss without a bail-in: This is the maximum loss that bank $i$ can suffer without violating the capitalization limits under which the bank must be bailed in, introduced in Section 4.2.2. $\bar{\varepsilon}_{i}^{N B}$ is computed as:

$$
\begin{aligned}
& V\left(x_{1}, x_{2}\right)=\frac{x_{1} R W A_{i} / 100-x_{2}}{x_{1} w_{i} / 100-1} \\
& \bar{\varepsilon}_{i}^{N B}=\min \left(V\left(I^{C}, K_{i}^{C}\right), V\left(I^{T 1}, K_{i}^{T 1}\right), V\left(I^{T}, K_{i}^{T}\right)\right), \\
& \bar{\varepsilon}_{i}^{N B}=\max \left(\bar{\varepsilon}_{i}^{N B}, 0\right) .
\end{aligned}
$$

This variable also can be interpreted as the minimum loss that puts bank $i$ in bail-in.

c) Minimum resources required for a bail-in: We compute the minimum resources required for a bail-in as the least amount needed for recapitalization of a bank $i$ if it is in bail-in (in this case, $\bar{\varepsilon}_{i}^{N B}=0$ ). If it is not, $\underline{R}_{i}$ is computed for the minimum loss $\bar{\varepsilon}_{i}^{N B}$ that puts bank $i$ in bail-in. The computation is performed from the target capitalization indexes $I_{R}^{C}, I_{R}^{T 1}$ and $I_{R}^{T}$.

$$
\begin{aligned}
& V\left(x_{1}, x_{2}\right)=\frac{x_{1} R W A_{i} / 100-x_{2}}{1-x_{1} w_{i} / 100}+\bar{\varepsilon}_{i}^{N B}, \\
& \underline{R}_{i}=\max \left(V\left(I_{R}^{C}, K_{i}^{C}\right), V\left(I_{R}^{T 1}, K_{i}^{T 1}\right), V\left(I_{R}^{T}, K_{i}^{T}\right), 0\right) .
\end{aligned}
$$

d) Resources required for a bail-in with full recapitalization: We compute the resources required for a bail-in with full recapitalization as the amount needed for recapitalization of a bank $i$ supposing that it has incurred a loss that left it with a zero capital buffer $K_{i}^{B}$. The computation is also performed from the target capitalization indexes $I_{R}^{C}, I_{R}^{T 1}$ and $I_{R}^{T}$.

$$
\begin{aligned}
& V\left(x_{1}, x_{2}\right)=\frac{x_{1} R W A_{i} / 100-x_{2}}{1-x_{1} w_{i} / 100}+K_{i}^{B}, \\
& \bar{R}_{i}=\max \left(V\left(I_{R}^{C}, K_{i}^{C}\right), V\left(I_{R}^{T 1}, K_{i}^{T 1}\right), V\left(I_{R}^{T}, K_{i}^{T}\right), 0\right) .
\end{aligned}
$$

e) Sufficiency of resources for a bail-in: If $\underline{R}_{i} \leq D_{i}^{B}$, bank $i$ has resources for being recapitalized if it suffers the minimum loss that triggers a bail-in (see Equation (C.2) or from its current condition, if $\bar{\varepsilon}_{i}^{N B}=0$.

f) Maximum loss absorbable with a bail-in: We compute the maximum absorbable loss in case the bank $i$ can be bailed in. This loss will be at least equal to that which the bank can bear without a 
bail-in (see Equation (C.2).) The way the computation is performed depends on the bank having bail-inable resources enough to allow the write-down of debts. This happens if these resources are greater than the required for fully recapitalizing the bank after a loss that leaves it with a zero capital buffer $K_{i}^{B}$. If this is the case, the maximum loss that the bank can bear is the sum of the capital buffer and the maximum bail-inable debt that can be written-down, considering that after the write-down, the bank must be recapitalized from a zero capital buffer condition. We compute the maximum amount of bail-inable debt that can be written-down $\overline{W D}_{i}$ as follows:

$$
\begin{aligned}
& V\left(x_{1}, x_{2}\right)=\frac{\left(1-x_{1} w_{i} / 100\right)\left(D_{i}^{B}-K_{i}^{B}\right)-\left(x_{1} R W A_{i} / 100-x_{2}\right)}{1-2 x_{1} w_{i} / 100} \\
& \overline{W D}_{i}=\min \left(V\left(I_{R}^{C}, K_{i}^{C}\right), V\left(I_{R}^{T 1}, K_{i}^{T 1}\right), V\left(I_{R}^{T}, K_{i}^{T}\right)\right) .
\end{aligned}
$$

If $\overline{W D}_{i}>0$, we compute the maximum loss absorbable with a bail-in $\bar{\varepsilon}_{i}^{B}$ as:

$$
\bar{\varepsilon}_{i}^{B}=K_{i}^{B}+\overline{W D}_{i}
$$

If bank $i$ 's bail-inable resources are less than the required for its recapitalization from a zero capital buffer condition, $\left(\overline{W D}_{i} \leq 0\right)$, the computation of the maximum loss bearable by the bank will consider these resources will be entirely employed in its recapitalization, as follows:

$$
\begin{aligned}
& V\left(x_{1}, x_{2}\right)=D_{i}^{B}-\frac{x_{1} R W A_{i} / 100-x_{2}}{1-x_{1} w_{i} / 100}, \\
& \bar{\varepsilon}_{i}^{B}=\min \left(V\left(I_{R}^{C}, K_{i}^{C}\right), V\left(I_{R}^{T 1}, K_{i}^{T 1}\right), V\left(I_{R}^{T}, K_{i}^{T}\right)\right) .
\end{aligned}
$$

Contagion variables: We define variables to quantify the contagion associated with resolution processes and assess the benefits of including a bail-in in a resolution process. These variables are computed for the entire banking system and are related to its response to a given initial scenario following a resolution process that may or may not include a bail-in.

a) Contagion losses: For a bank $i$, we define contagion losses as those that exceed the initial shock $\varepsilon_{i}^{1}$ it suffers due to the scenario under analysis. We compute the banking system contagion losses $E^{P}$ after the completion of the resolution process $P$ being studied, i.e., in iteration $t$, as follows:

$$
E^{P}=\sum_{i \in \mathscr{B}} \varepsilon_{i}(t)-\varepsilon_{i}(1)
$$

In the equation above, $P$ equals $B$ or $N B$ denoting the resolution process type that includes or not a bail-in. 
b) Total contagion losses: We define the banking system's total contagion losses as the sum of its contagion losses in Equation (C.8) with the liquidation costs (residual assets for recovery) of liquidated banks, computed from Equation (27), for a resolution process that includes a bail-in. These assets are temporarily frozen during the liquidation of a bank before being recovered by the bank's creditors. Therefore, total contagion losses is a measure to quantify short-term losses. For the resolution process type $P, E^{T, P}$ is given by:

$$
E^{T, P}=E^{P}+\sum_{i \in \mathscr{L}} A_{i}^{R, P}
$$

c) Mitigation of total contagion per unit of absorbed loss: This variable is a measure the effectiveness of a bail-in process. It is computed for a given scenario as a ratio between the total contagion losses mitigated by the bail-in process and the total debt used for absorbing losses during the bail-ins, either by write-downs or by conversion into shares. The mitigation of contagion losses is computed as the difference between the banking system's total contagion losses computed for the resolution process without a bail-in and those computed for the process that includes a bail-in, meaning how much loss the banking system avoided by adopting the bail-in process proposed in this paper. The denominator of the ratio is computed as the variation of debt balance of the proper seniorities from the initial balance to that after the process finished, and provides a measure of the effort needed for the contagion's mitigation. The variable is computed as:

$$
M^{L}=\frac{E^{T, N B}-E^{T, B}}{\sum_{i \in \mathscr{B}}\left(D_{i}^{1}(0)-D_{i}^{1}(t)\right)+\sum_{j \in \mathscr{D}}\left(D_{j}^{2}(0)-D_{j}^{2}(t)\right)} .
$$

In this equation, $\mathscr{D}$ is the set of D-SIBs and $T$ is the number of the last iteration of the resolution process.

d) Mitigation of credit crunch per unit of absorbed loss: This variable measures another dimension of the effectiveness of a bail-in process: the credit crunch that occurs when a bank is liquidated, forcing firms who would borrow from it to find another credit provider. This constraint affects the real sector as it reduces the financial system's credit supply. We follow the same principles used for the definition of the variable presented in the previous item and use Equation (28) to define the mitigation of credit crunch per unit of absorbed loss as:

$$
M^{C}=\frac{C C^{N B}-C C^{B}}{\sum_{i \in \mathscr{B}}\left(D_{i}^{1}(0)-D_{i}^{1}(t)\right)+\sum_{j \in \mathscr{D}}\left(D_{j}^{2}(0)-D_{j}^{2}(t)\right)} .
$$

